Article

\title{
Biomineralization of Carbonate Minerals Induced by The Moderate Halophile Staphylococcus Warneri YXY2
}

\author{
Yu Han ${ }^{1,2}$, Bin Sun ${ }^{1, *}$, Huaxiao Yan ${ }^{1,2}$, Maurice E. Tucker ${ }^{3,4}$, Yanhong Zhao ${ }^{1}$, Jingxuan Zhou ${ }^{1}$, \\ Yifan Zhao ${ }^{1}$ and Hui Zhao ${ }^{1, *}$ \\ 1 College of Earth Science and Engineering, College of Chemical and Biological Engineering, \\ Shandong Provincial Key Laboratory of Depositional Mineralization and Sedimentary Minerals, \\ Shandong University of Science and Technology, Qingdao 266590, China; hanyugenius91@163.com (Y.H.); \\ 15954804511@163.com (H.Y.); zhaoyanhong65@126.com (Y.Z.); 15689435926@163.com (J.Z.); \\ zsj371481@163.com (Y.Z.) \\ 2 Laboratory for Marine Mineral Resources, Center for Isotope Geochemistry and Geochronology, \\ Qingdao National Laboratory for Marine Science and Technology, Qingdao 266237, China \\ 3 School of Earth Sciences, University of Bristol, Bristol BS8 1RJ, UK; glmet@bristol.ac.uk \\ 4 Cabot Institute, University of Bristol, Cantock's Close, Bristol BS8 1UJ, UK \\ * Correspondence: sunbin2012@163.com (B.S.); zhsdust@sdust.edu.cn (H.Z.); \\ Tel.: +86-532-86-057-813 (B.S.); +86-532-86-057-813 (H.Z.)
}

Received: 4 January 2020; Accepted: 21 January 2020; Published: 22 January 2020

\begin{abstract}
Although biomineralization of minerals induced by microorganisms has been widely reported, the mechanisms of biomineralization and the characteristics of the biominerals precipitated needs to be studied further. In this study, Staphylococcus warneri YXY2, a moderate halophile, was used to induce the precipitation of carbonate minerals at various $\mathrm{Mg} / \mathrm{Ca}$ molar ratios. To investigate the biomineralization mechanism, the growth curve, $\mathrm{pH}$ changes, ammonia test, the concentration of bicarbonate and carbonate ions, and the activity of carbonic anhydrase (CA) and alkaline phosphatase (ALP) were determined. X-ray powder diffraction (XRD), scanning electron microscopy - energy disperse spectroscopy (SEM-EDS), Fourier transform infrared spectroscopy (FTIR), X-ray photoelectron spectroscopy (XPS), scanning transmission electron microscopy (STEM), and stable carbon isotope analyses were used to characterize the minerals. The obtained biotic minerals were calcite, vaterite, Mg-rich calcite, and aragonite crystals. The crystallinity of aragonite decreased with increasing $\mathrm{Mg} / \mathrm{Ca}$ ratios. The preferred orientation, diverse morphologies, organic substances, and more negative stable carbon isotope values proved the biogenesis of these carbonate minerals. The presence of $\mathrm{Mg}$ in the biotic aragonite crystals was likely related to the acidic amino acids which also facilitated the nucleation of minerals on/in the extracellular polymeric substances (EPS). $\mathrm{Mg}^{2+}$ and $\mathrm{Ca}^{2+}$ ions were able to enter into the YXY2 bacteria to induce intracellular biomineralization. Dynamics simulation using Material Studio software proved that different adsorption energies of Glutamic acid (Glu) adsorbed onto different crystal planes of aragonite led to the preferred orientation of aragonite. This study helps to deepen our understanding of biomineralization mechanisms and may be helpful to distinguish biotic minerals from abiotic minerals.
\end{abstract}

Keywords: Staphylococcus warneri; moderate halophilic bacteria; $\mathrm{Mg} / \mathrm{Ca}$; aragonite; molecular simulation; biomineralization; preferred orientation

\section{Introduction}

The effects of microorganisms and their metabolic activities on the biomineralization of carbonate minerals have been widely investigated [1-5]. Research into biotic carbonate minerals induced by cyanobacteria, sulfate-reducing bacteria, halophiles, and other microorganisms has made great 
progress [5-10]. To explore the formation mechanism of microbialites, halophiles have been used to induce the precipitation of carbonate minerals by simulating the saline palaeoenvironment in the laboratory. Rivadeneyra et al. studied the precipitation of biotic carbonate minerals induced by Halobacillus trueperi and found that Ca-Mg kutnahorite and huntite could be precipitated in the presence of halophiles [11]. Sánchez-Román successfully induced dolomite and Mg-rich carbonate minerals using different aerobic bacterial strains and concluded that the carbon isotope composition of the biotic carbonate minerals related to the influence of microorganisms [12]. In addition, Qiu et al. investigated dolomite formation induced by Haloferax volcanii DS52 and emphasized the important role played by extracellular polymeric substances (EPS); they showed that carboxyl groups of amino acids influenced the dehydration of $\mathrm{Mg}\left[\mathrm{H}_{2} \mathrm{O}_{6}\right.$ which favored dolomite formation [13]. Carbonate minerals induced by the halophile Chromohalobacter israelensis was also studied in the previous research [5], and the results showed that different sources of $\mathrm{Mg}^{2+}$, e.g., magnesium chloride $\left(\mathrm{MgCl}_{2}\right)$ and magnesium sulfate $\left(\mathrm{MgSO}_{4}\right)$, could significantly affect the morphologies and crystallinities of carbonate minerals, resulting in different kinds of minerals. However, the biomineralization of carbonate minerals induced by the moderate halophile Staphylococcus warneri YXY2 has rarely been reported.

The important roles played by microorganisms in biomineralization have been widely explored [14-18], but there are still different opinions concerning some particular issues. As for the nucleation sites in the precipitation process of biotic minerals $[5,8,9,13-22]$, some scientists have suggested that the cell wall can act as the nucleation site, while others have proposed that extracellular polymeric substances (EPS) loosely enveloping the cell wall are the true nucleation sites. One species of sulfate-reducing bacterium, Desulfovibrio bizertensis, was inoculated into a culture medium at various $\mathrm{Mg} / \mathrm{Ca}$ molar ratios to induce the formation of minerals, at the same time using calcite and kaolinite as seeding materials [15], and the results showed that most carbonate minerals formed on the cell surface and not the seeding materials, indicating that the bacterial cell wall alone could serve as the nucleation sites in the induction process. Deng et al. [14] investigated the precipitation of dolomite induced by the sulfate-reducing bacterium Desulfotomaculum ruminis and halophile Halomonas marina and found that EPS could be regarded as the nucleation site. There are also other opinions about the nucleation site. During biomineralization of carbonate minerals induced by halophile Chromohalobacter israelensis, EPS, and intracellular vesicles were suggested as the nucleation sites [5]. In addition, many investigations have demonstrated that microbial metabolism can provide a favorable environment for the precipitation of carbonate minerals [7,16-20]. Achal and Pan investigated the characteristics of urease and carbonic anhydrase (CA) and demonstrated their roles in microbially-induced biomineralization [21]. Krause et al. examined carbonate precipitation under the catalysis of CA and found that CA could significantly increase the rate of precipitation [22]. However, there have been few reports concerning CA's important role in $\mathrm{pH}$ increase. In general, the release of ammonia by bacteria increasing $\mathrm{pH}$ has been widely accepted by almost all the researchers. However, in this study, $\mathrm{pH}$ did not increase beyond 8.5 just under the effect of ammonia, thus, $\mathrm{pH}$ increasing above 8.5 in the presence of bacteria would only take place through other factors. In this study, CA and its product carbonate and bicarbonate ions were proved to play an important role in promoting $\mathrm{pH}$ increase. Alkaline phosphatase (ALP) was the same as $\mathrm{CA}$, also promoting $\mathrm{pH}$ increase. Therefore, the mechanism of biomineralization should be further explored.

Besides the investigation of the mechanisms of biomineralization, there are several other unresolved issues that warrant further study, including what factors control or influence the calcium carbonate polymorphs precipitated? Why can the $\mathrm{Mg}^{2+}$ ion enter into the biogenic aragonite lattice but not into a chemically synthesized aragonite? What significant differences are there between the biotic and abiotic minerals?

In order to further understand the exact mechanism of biomineralization induced by halophiles, the moderate halophile $S$. warneri $\mathrm{YXY} 2$ was used to induce the precipitation of carbonate minerals with various $\mathrm{Mg} / \mathrm{Ca}$ ratios. The growth curve, $\mathrm{pH}$ changes, $\mathrm{CA}$ and ALP activity, the concentrations of ammonium $\left(\mathrm{NH}_{4}{ }^{+}\right)$, carbonate and bicarbonate ions, the organic substances and amino acid 
composition in the EPS were tested. The mineralogy, morphology, elemental composition and organic substances within minerals were analyzed using X-ray powder diffraction (XRD), scanning electron microscope (SEM), energy dispersive spectrometer (EDS), Fourier transform infrared spectroscopy (FT-IR) and X-ray photoelectron spectroscopy (XPS). To further prove the biogenesis of these minerals, the stable carbon isotope values were also measured. Intracellular dark inclusions were examined using high-resolution transmission electron microscopy (HRTEM) and scanning transmission electron microscopy (STEM). In addition to these experiments, simulation of aragonite formation in the presence of glutamic acid (Glu) was also conducted using Material Studio software 8.0 in order to explain the entry of $\mathrm{Mg}$ into aragonite crystals and their preferred orientation. This study can provide some references for further understanding of the mechanism of the formation of microbially-induced carbonate minerals.

\section{Materials and Methods}

\subsection{Culture Medium and Bacterial Strain}

The components of the liquid medium were as follows: beef extract $\left(3 \mathrm{~g} \cdot \mathrm{L}^{-1}\right)$, tryptone $\left(10 \mathrm{~g} \cdot \mathrm{L}^{-1}\right)$, potassium chloride $\left(\mathrm{KCl}, 2 \mathrm{~g} \cdot \mathrm{L}^{-1}\right)$, and sodium chloride $\left(\mathrm{NaCl}, 100 \mathrm{~g} \cdot \mathrm{L}^{-1}\right)$ [5]. The solid medium was obtained by adding $20 \mathrm{~g} \cdot \mathrm{L}^{-1}$ agar into the liquid medium, and $\mathrm{pH}$ values of the solid and liquid mediums were adjusted to 7.0. The S. warneri YXY2 strain used in this experiment was preserved at $-20{ }^{\circ} \mathrm{C}$ in our lab, which was isolated from Yinjiashan Saltern along the Yellow Sea in China. Its $16 \mathrm{~S}$ rDNA sequences were submitted to GenBank and the obtained accession number was MF807933.

\subsection{Preparation of Bacterial Seed}

S. warneri YXY2 bacteria were daubed on the solid culture medium and then cultured at $30{ }^{\circ} \mathrm{C}$ for three days until the single colony grew to reach 1 to $2 \mathrm{~mm}$ in diameter. One colony was chosen and inoculated into the liquid medium, then cultured in a constant temperature oscillating incubator (HZQ-F160, Harbin Donglian Electronic Technology Development Co., Ltd., Harbin, China) with a speed of $120 \mathrm{rpm}$ at $30^{\circ} \mathrm{C}$ until its $\mathrm{OD}_{600}$ value reached 1.0. The above cultured bacterial solution could be used as the bacterial seed to perform the following experiments. The seed was inoculated into the liquid culture medium at a volume ratio of $1 \%$.

\subsection{Physiological and Biochemical Characteristics of YXY2 Bacteria}

The cell concentrations of YXY2 bacteria were measured using a spectrophotometer (UNIC7200, Shanghai Sainty Hengfeng Scientific Instrument Co., Ltd., Shanghai, China) at a wavelength of $600 \mathrm{~nm}$, and $\mathrm{pH}$ values were measured by a pH meter (PHS-3, Jiangsu Jiangfen Instrument and Equipment Company, China) [23-25]. The liquid culture medium inoculated with YXY2 bacteria $\left(\mathrm{OD}_{600}=1.0\right)$ at a volume ratio of 1:100 was set as the experimental group, and that inoculated with the same volume ratio of sterilized distilled water was set as the control group. Ammonia test of YXY2 bacteria, the concentration of ammonium ion, CA activity, concentrations of carbonate and bicarbonate ions, the calculation of $\mathrm{pH}$ values based on the concentration of ammonium, bicarbonate and carbonate ions were all conducted according to published papers [26-29]. ALP activities were measured according to a previous study [30] and the concentrations of phosphate ions were also measured with the molybdenum blue method [31]. The sodium phosphate $\left(\mathrm{Na}_{3} \mathrm{PO}_{4}\right)$ solutions were prepared according to the $\mathrm{PO}_{4}{ }^{3-}$ concentration and $\mathrm{pH}$ values of the $\mathrm{Na}_{3} \mathrm{PO}_{4}$ solutions were measured using the $\mathrm{pH}$ meter.

EPS of S. warneri YXY2 were extracted using the heating method [16,25], then, the amino acids in the harvested EPS were detected using an amino acid analyzer (Hitachi L-8900, Hitachi Co., Tokyo, Japan) by Jiangsu Coastal Chemical Analysis \& Technological Service Ltd (Jiangsu, China). 


\subsection{Formation of Biotic and Abiotic Carbonate Minerals}

In the liquid medium used to induce the carbonate minerals, calcium chloride $\left(\mathrm{CaCl}_{2}\right)$ was added and the concentration of $\mathrm{Ca}^{2+}$ was $0.01 \mathrm{~mol} \cdot \mathrm{L}^{-1}$, and magnesium chloride hexahydrate $\left(\mathrm{MgCl}_{2} \cdot 6 \mathrm{H}_{2} \mathrm{O}\right)$ was used to adjust the $\mathrm{Mg} / \mathrm{Ca}$ ratios $(0,2,4,6$, and 8), $\mathrm{pH}$ was adjusted to 7.0. Then YXY2 bacterial seed $\left(\mathrm{OD}_{600}=1.0\right)$ was inoculated into the culture medium at a volume ratio of $1 \%$, which was set as the experimental group. The control group was inoculated with $1 \%$ of sterilized distilled water (volume ratio), not the bacterial seed. There were three parallel samples at each $\mathrm{Mg} / \mathrm{Ca}$ molar ratio in the experimental and control groups, and each sample solution is $150 \mathrm{~mL}$. To avoid the influence of atmospheric carbon dioxide, a conical flask containing the sample solution was sealed with a sealing film to isolate the solution from the air. All the cultures were placed in a constant temperature oscillating incubator with a speed of $120 \mathrm{rpm}$ at $30^{\circ} \mathrm{C}$. Abiotic calcite and aragonite were prepared using the published method [16,32], respectively.

\subsection{Characterization of Biominerals Induced by YXY2 Bacteria}

Precipitates were obtained in the experimental group but were not harvested in the control group after 14 days of cultivation. The precipitates were analyzed with XRD (Ultima IV, Japan) [33] with a scanning angle from $10^{\circ}$ to $60^{\circ}, 0.02^{\circ}$ per step and a scanning speed of $8^{\circ} \cdot \mathrm{min}^{-1}$, and then the obtained data were analyzed using the MDI Jade 6.5 software to determine the mineral phase. The weight percent of each mineral in the mixture was calculated using the Material Studio 8.0 software. The morphology and elemental composition of these biotic minerals were analyzed with SEM (S4800, Hitachi, Japan) and EDS (EDAX XM2-60S, Hitachi, Japan). Meantime, the organic substances in the biominerals were analyzed by Fourier transform infrared spectroscopy (FTIR, Nicolet 380, Thermol Electron Corporation, Waltham, MA, USA) with a wavenumber range of $4000-500 \mathrm{~cm}^{-1}$. The surface chemistry of the aragonite was also determined using XPS (Thermo ESCALAB 250XI, ThermoFisher, Waltham, MA, USA) with a step size of $0.05 \mathrm{eV}$. Charge correction was performed with C1s (284.80 Ev) as standard binding energy.

The biotic aragonite at an $\mathrm{Mg} / \mathrm{Ca}$ molar ratio of 8 and abiotic aragonite crystals were washed with deionized water several times. When the $\mathrm{Mg}^{2+}$ ions could not be detected in the supernatant, it meant that $\mathrm{Mg}^{2+}$ ions adsorbed on the mineral surface were thoroughly washed off. Then the aragonite crystals were ground into nanoparticles in an agate mortar, and sodium hypochlorite was added to wash the aragonite nanoparticles at least three times until that no bubbles could be observed. The clean nano-sized aragonite powder was dried at room temperature. One part of aragonite powder was suspended in anhydrous ethanol, a drop of suspension was dripped on the copper net, after being dried at room temperature, analyzed with high-resolution transmission electron microscope (HRTEM, JEM-2100, Japan Electron Optics Laboratory, Japan) [34] and scanning transmission electron microscopy (STEM, Tecnai G2 F20, FEI, USA). The other part of aragonite powder was dissolved in 1\% $\mathrm{HCl}$ solution-at last, the concentration of $\mathrm{Mg}^{2+}$ ions was measured using flame atomic absorption spectrometry (FAAS) (TAS-986F, Persee General Instrument Co., LTD., Beijing, China).

The stable carbon isotope analyses of the biotic and abiotic carbonate minerals and organic substances in the culture medium were performed with an isotope analyzer (Picarro G2121-i, Picarro Inc., Santa Clara, CA, USA) according to the published methods [16].

Thermogravimetric analyses (TG), derivative thermogravimetric analyses (DTG), and differential scanning calorimetry (DSC) were used to analyze the thermal characteristics of the biotic and abiotic aragonite. Biotic and abiotic aragonite crystals were ground into a powder and filtered with a 400-mesh sieve, respectively. The powder was analyzed by a thermal analyzer (TGA/ dsc1/1600lf, METTLER TOLEDO Co., Switzerland) with the temperature range of 50 to $1000{ }^{\circ} \mathrm{C}$ and at a heating rate of $10^{\circ} \mathrm{C}$ per minute. Nitrogen was used as a protective gas to prevent oxidation. 


\subsection{Analyses of Intracellular Biomineralization}

Fluorescence intensities of intracellular $\mathrm{Ca}^{2+}$ ions at various $\mathrm{Mg} / \mathrm{Ca}$ ratios were measured with a fluorescence spectrophotometer (Hitachi F-4600, Hitachi, Japan) [16]. Cells stained with Fluo-3 AM were set as the experimental groups while cells not stained by Fluo-3 AM were set as the control groups. Ultrathin slices of $S$. warneri YXY2 bacteria in the experimental and control groups were prepared [27] and then analyzed with high-resolution transmission electron microscopy (HRTEM, JEM-2100, Japan Electronics Company, JEOL, Japan) and selected area electron diffraction (SAED). Elemental mapping was also conducted with a scanning transmission electron microscope (STEM, Tecnai G2 F20, FEI, Hillsboro, OR, USA). YXY2 bacteria cultured at different $\mathrm{Mg} / \mathrm{Ca}$ ratios were set as the experimental groups-those cultured in the liquid culture mediums without any $\mathrm{Ca}^{2+}$ and $\mathrm{Mg}^{2+}$ ions were set as the control groups.

\subsection{Molecular Dynamics Simulation}

Molecular dynamics simulation of the biotic aragonite under the influence of Glu was performed using Material Studio software 8.0. All the simulations and calculations were performed with the Discover module of Material Studio software 8.0.

\section{Results}

\subsection{Hydro-Chemical Parameters' Evolutions}

After Blast in Genbank, 16s rDNA sequences of YXY2 bacteria were the same as those of a large number of bacteria belonging to the species of Staphylococcus warneri. The confidence coefficient in the phylogenetic tree was 100 when comparing 16s rDNA sequences of YXY2 bacteria and those of Staphylococcus warneri AW 25 (Figure S1 in supplementary materials). Therefore, YXY2 bacteria were identified as the species of Staphylococcus warneri.

As seen in Figure S2a1, the control group was clear and transparent before adding Nessler's reagent (tube 1), and the experimental group was turbid (tube 2) because of the presence of YXY2 bacteria. After adding Nessler's reagent (Figure S2a2), the experimental group turned brownish (tube 2), and the control group changed to light yellow (tube 1). The yellow color displayed the color of Nessler's reagent. Thus, halophile YXY2 could release ammonia.

The growth curve of $S$. warneri YXY2 bacteria can be divided into four phases (Figure 1a): the adaption phase, the logarithmic growth phase, the stationary phase, and the decline phase. At the beginning, the bacteria grew slowly in the adaption phase during the first $12 \mathrm{~h}$-at this time range $\mathrm{pH}$ values showed a slight decline. The second phase was the logarithmic phase in the time range of 12 to $44 \mathrm{~h}$, and the cell concentration sharply increased, accompanied by increasing $\mathrm{pH}$ due to the production of $\mathrm{NH}_{3}$. The time range of 44 to $54 \mathrm{~h}$ belonged to the stationary phase, during this period, the cell concentration remained nearly stable while $\mathrm{pH}$ still increased. In the last phase, that was the decline stage, the cell concentration declined over a period of 54-144 h due to the lack of nitrogenous nutrients [9,35]. In the decline stage, the $\mathrm{pH}$ in the experimental group still increased until it reached 8.65, and then kept constant. The $\mathrm{pH}$ values of the control group were almost stable, near 7.0.

The concentrations of $\mathrm{NH}_{4}^{+}$ions in the medium inoculated with YXY2 bacteria are shown in Figure $1 \mathrm{~b}$. In the beginning, $\mathrm{NH}_{4}^{+}$was not detected until the $24^{\text {th }}$ hour, then increased from 0 to $1.55 \times 10^{-6} \mathrm{~mol} \cdot \mathrm{L}^{-1}$ in the logarithmic phase from $24 \mathrm{~h}$ to $54 \mathrm{~h}$, and then remained nearly stable from $54 \mathrm{~h}$ to $144 \mathrm{~h}$ (Figure $1 \mathrm{~b}$ ). Seen from the $\mathrm{pH}$ curve based on the concentration of $\mathrm{NH}_{4}^{+}$(Figure 1a), $\mathrm{pH}$ increased to 8.22 and then remained stable, indicating that the released ammonia was not enough to make $\mathrm{pH}$ increase to 8.65 . In the decline stage, $\mathrm{pH}$ still increased in the experimental group, indicating that there must be other factors causing $\mathrm{pH}$ to increase besides ammonia because the bacteria could not release any more ammonia due to the lack of nitrogenous substances in the decline stage. 

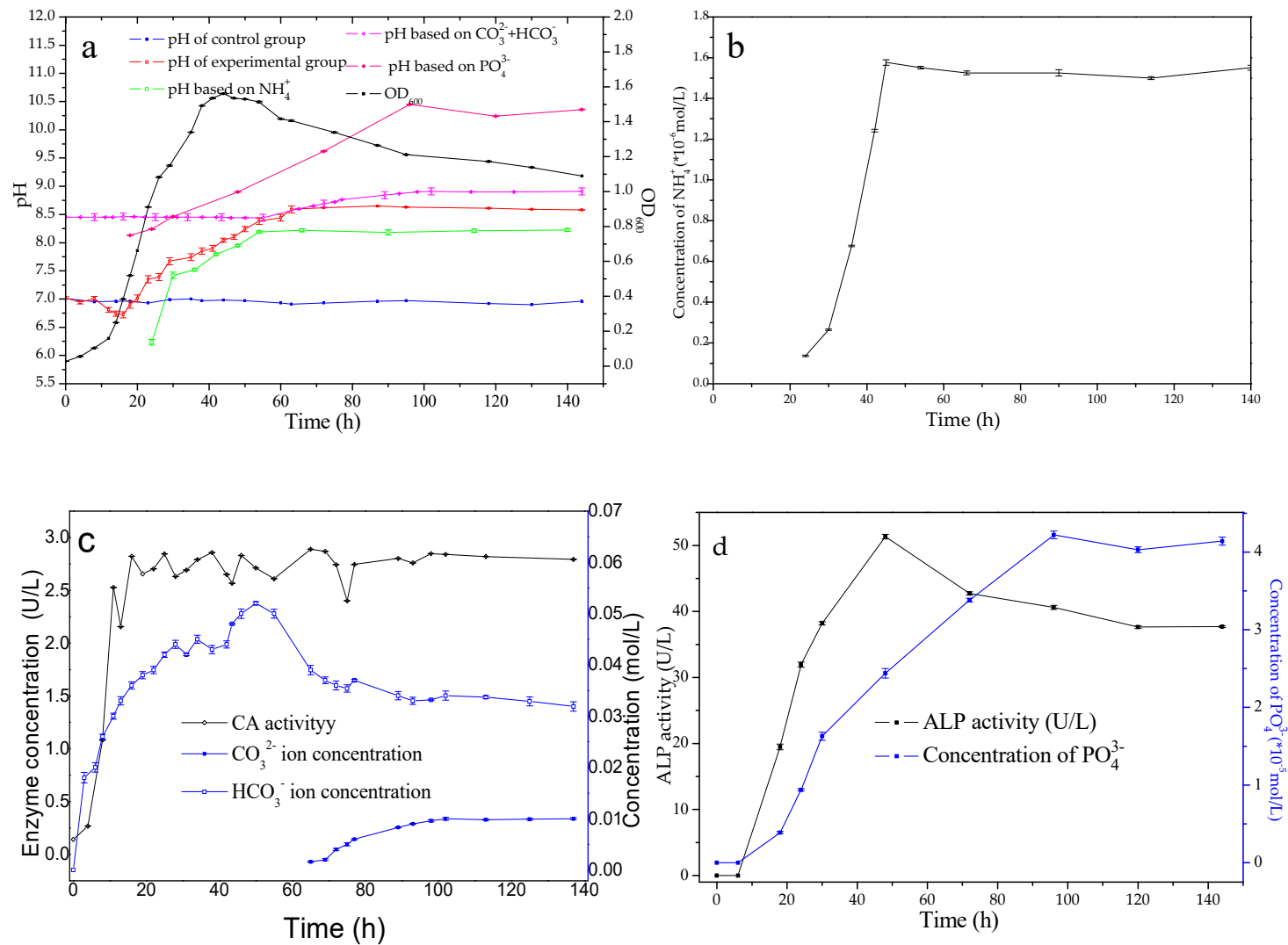

Figure 1. Biochemical characteristics of $S$. warneri $\mathrm{YXY} 2$ bacteria. (a), growth curve and $\mathrm{pH}$ curves; (b), $\mathrm{NH}_{4}{ }^{+}$concentration; (c), CA activity and the concentration of $\mathrm{CO}_{3}{ }^{2-}$ and $\mathrm{HCO}_{3}{ }^{-} ;(\mathbf{d}), \mathrm{ALP}$ activity and the concentration of $\mathrm{PO}_{4}^{3-}$.

As shown in Figure 1c, CA activity increased from 0.02 to $2.84 \mathrm{U} \cdot \mathrm{L}^{-1}$ in the time range of 0 to $16 \mathrm{~h}$, then almost kept constant in the time range of 16 to $137 \mathrm{~h}$. Alkaline CA can catalyze the hydration of carbon dioxide $\left(\mathrm{CO}_{2}\right)$ to produce a large number of bicarbonate and carbonate ions. Thus, the concentrations of bicarbonate and carbonate ions were also measured. The concentration of bicarbonate ions increased from 0.018 to $0.052 \mathrm{~mol} \cdot \mathrm{L}^{-1}$ in the time range of 0 to $50 \mathrm{~h}$, decreased to $0.031 \mathrm{~mol} \cdot \mathrm{L}^{-1}$ at $98 \mathrm{~h}$, and then remained nearly stable (Figure 1c). Carbonate ions were not detected until $65 \mathrm{~h}$, then increased from 0.0016 to $0.01 \mathrm{~mol} \cdot \mathrm{L}^{-1}$ in the time range of 65 to $102 \mathrm{~h}$ and remained almost constant from 102 to $137 \mathrm{~h}$ (Figure 1c). It was noteworthy that when the concentration of bicarbonate decreased, the concentration of carbonate increased, indicating that bicarbonate was transformed into carbonate ions. The production of bicarbonate and carbonate ions also contributed to the $\mathrm{pH}$ increase in the culture medium. The $\mathrm{pH}$ of (bicarbonate + carbonate) solution was always higher than that resulting from ammonia, and also higher than that of the experimental group (Figure 1a), indicating that the released bicarbonate and carbonate ions also led to $\mathrm{pH}$ increase. The $\mathrm{pH}$ increase in the bacterial decline stage could be due to this reason.

ALP could also be released, and ALP activity increased from 0 to $51.33 \mathrm{U} \cdot \mathrm{L}^{-1}$ in the time range of 0 to $48 \mathrm{~h}$, and then decreased to $37.71 \mathrm{U} \cdot \mathrm{L}^{-1}$ at $144 \mathrm{~h}$ (Figure $1 \mathrm{~d}$ ). The concentration of $\mathrm{PO}_{4}^{3-}$ ions, the product of ALP catalysis, increased from 0.38 to $4.22 \times 10^{-5} \mathrm{~mol} \cdot \mathrm{L}^{-1}$ in the time range of 18 to $96 \mathrm{~h}$, and then remained almost constant (Figure 1d). The pH based on the phosphate (Figure 1a) was higher than that of the experimental group, indicating that ALP and phosphate ions also led to $\mathrm{pH}$ increase.

\subsection{Characteristics of Biominerals}

In the experimental groups, the obtained minerals were calcite $(92.01 \%$, mass ratio) and vaterite (7.99\%, mass ratio) at a $\mathrm{Mg} / \mathrm{Ca}$ ratio of $0, \mathrm{Mg}$-rich calcite and aragonite at $\mathrm{Mg} / \mathrm{Ca}$ ratios of 2, 4, 
and 6, and only aragonite at a $\mathrm{Mg} / \mathrm{Ca}$ ratio of 8 (Figure 2, Figure S3). The mass ratio of $\mathrm{Mg}$-rich calcite decreased from $27.7 \%$ to $10.8 \%$ when the $\mathrm{Mg} / \mathrm{Ca}$ molar ratio increased from 2 to 6 , and that of aragonite increased from $72.3 \%$ to $89.2 \%$ (Figure S3b-d), indicating that lower concentrations of $\mathrm{Mg}^{2+}$ ions were beneficial to the formation of $\mathrm{Mg}$-rich calcite and higher concentrations of $\mathrm{Mg}^{2+}$ ions could promote the formation of aragonite. Full width at half maximum (FWHM) values of aragonite increased and density decreased with increasing $\mathrm{Mg} / \mathrm{Ca}$ ratios (Table S1 in supplementary materials), illustrating that aragonite crystallinity was less well developed with increasing $\mathrm{Mg} / \mathrm{Ca}$ ratios. FWHM values of the abiotic aragonite were greater than those of the biotic aragonite at an $\mathrm{Mg} / \mathrm{Ca}$ ratio of 8 (Table S2), indicating that aragonite crystallinity was better developed with the participation of the YXY2 bacterium. The intensity of the crystal plane (012) was higher than that of the crystal plane (221) for the standard aragonite (PDF 41-1475). However, for the biotic aragonite in this study, the opposite was true: the intensity of crystal plane (221) was stronger than that of crystal plane (012) (Figure 2), indicating that a preferred orientation occurred within the aragonite crystals at an $\mathrm{Mg} / \mathrm{Ca}$ molar ratio of 8 .

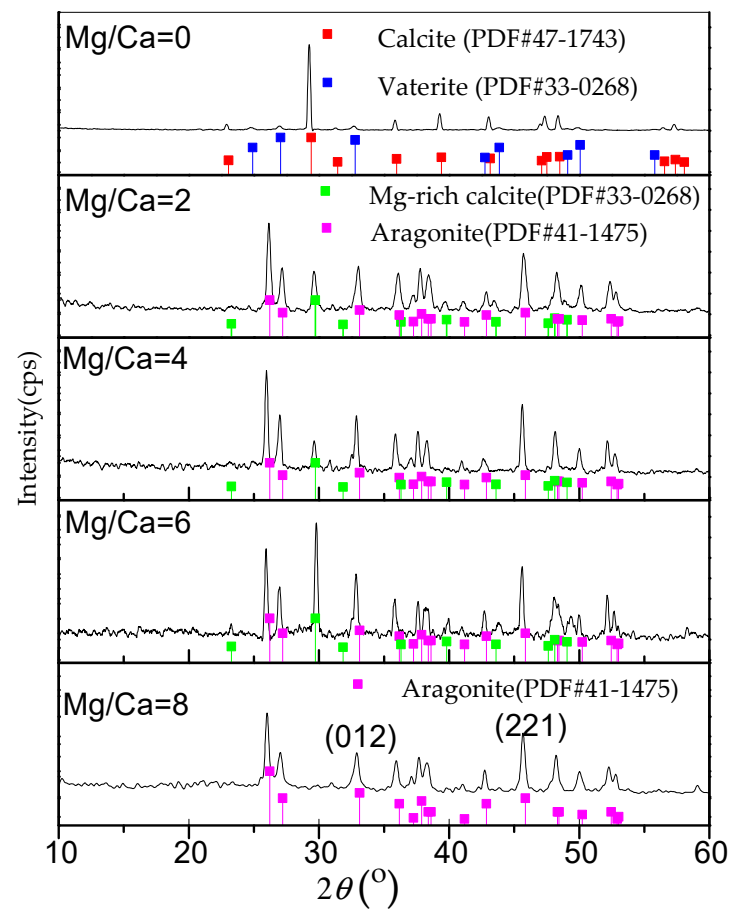

Figure 2. X-ray diffraction analyses of the biotic minerals cultivated for 14 days.

The minerals at an $\mathrm{Mg} / \mathrm{Ca}$ ratio of 0 are mainly elongate or rod-shaped (Figure 3a1), and also rhombohedron-shaped (Figure 3a3). Many holes, a width of about $0.6 \mu \mathrm{m}$ and a length of $1.0 \mu \mathrm{m}$ (Figure 3a2), very similar in size to the YXY2 bacteria, are embedded in the rod-shaped mineral surface (Figure 3a2), suggesting that these were the 'hiding places' of bacteria, and also further revealing that the formation of the rod-shaped mineral was closely related to YXY2 bacteria. The rhombohedron-shaped mineral is composed of a large number of scale-like crystals that have sharp angles (Figure 3a4). The elemental composition of the minerals at $\mathrm{Mg} / \mathrm{Ca}$ ratio of 0 is mainly $\mathrm{C}, \mathrm{O}, \mathrm{Ca}$, and a small amount of $\mathrm{Al}$, $\mathrm{Na}$, and $\mathrm{P}$ (Figure 3a5,6). $\mathrm{Na}$ was from $\mathrm{NaCl}$ in the culture medium and $\mathrm{Al}$ came from the upholder. The P element maybe came from bacteria YXY2, the metabolic products, and the organic components in the culture medium. The minerals at an $\mathrm{Mg} / \mathrm{Ca}$ ratio of 2 are mainly rhombohedron- (Figure 3b1) and dumbbell-shaped (Figure 3b2). The surface of rhombohedron-shaped minerals (Figure 3b1) is slightly different from that of the rhombohedron-shaped minerals without $\mathrm{Mg}^{2+}$ (Figure 3a4), indicating that $\mathrm{Mg}^{2+}$ can affect the micromorphology of minerals. The dumbbell-shaped minerals (Figure 3b2) are composed of many acicular crystals that diverge outward (Figure 3b3). From the EDS image 
(Figure 3b4), minerals in Figure $3 \mathrm{~b} 1$ include $\mathrm{C}, \mathrm{O}, \mathrm{Ca}, \mathrm{Mg}, \mathrm{Na}, \mathrm{Al}$ and $\mathrm{P} . \mathrm{Mg}$ was detected within the minerals, indicating that $\mathrm{Mg}$ maybe could enter the crystal lattice that led to the changes in the micromorphology of minerals. Rod-shaped minerals are observed at an $\mathrm{Mg} / \mathrm{Ca}$ ratio of 4 (Figure $3 \mathrm{c} 1$ ) and the fault structure with smooth edges is seen on its rough surface (Figure 3c2). In addition, shamrock-like minerals are also observed (Figure 3c3), on the surface of which both irregularly shaped particles and fault structures were observed (Figure 3c4). Minerals in Figure 3c1, c3 contain the elements $\mathrm{C}, \mathrm{O}, \mathrm{Ca}, \mathrm{Mg}, \mathrm{Na}, \mathrm{Al}$, and $\mathrm{P}$ (Figure 3c5,6), and the origins of these elements are the same as those mentioned above. At an $\mathrm{Mg} / \mathrm{Ca}$ ratio of 6 , rod-shaped minerals have two rough ends (Figure 3d1), which are covered by irregularly shaped particles (Figure 3d2). EDS results show the elemental composition (Figure 3d3), and the origins are the same as those mentioned above. Spindle-shaped minerals are observed (Figure $3 \mathrm{e} 1$ ) at an $\mathrm{Mg} / \mathrm{Ca}$ ratio of 8 , and spherical protrusions are also seen on the rough surfaces (Figure 3e1,2). Some holes, with a length of 0.6 to $1 \mathrm{um}$, are also present on the mineral surface (Figure 3e2). Besides, large spherical projections and very fine granular projections (Figure 3e4) are present on the minerals (Figure 3e3). EDS results also show that the elemental composition of minerals at a $\mathrm{Mg} / \mathrm{Ca}$ ratio of 8 (Figure 3e5) include $\mathrm{C}, \mathrm{O}, \mathrm{Ca}, \mathrm{Mg}, \mathrm{Na}, \mathrm{P}$, and $\mathrm{Al}$. The origins of these elements are the same as those mentioned above. The presence of the $\mathrm{Mg}$ element may indicate that $\mathrm{Mg}$ ions entered into the biogenic aragonite lattice.

After the ultrasonic treatment of the biotic aragonite, the supernatant was also analyzed with the FAAS method. $\mathrm{Mg}^{2+}$ ion in the supernatant could not be detected, indicating that $\mathrm{Mg}^{2+}$ ions adsorbed on the mineral surface were completely washed away. As shown in Figure S4, $\mathrm{Mg}^{2+}$ ions within the biotic aragonite were detected while there were no $\mathrm{Mg}^{2+}$ ions detected in the abiotic aragonite, revealing that $\mathrm{Mg}^{2+}$ ions could enter into the biotic aragonite crystals but not into the abiotic aragonite.

The STEM results (Figure 4) show the distribution of $\mathrm{Mg}, \mathrm{Ca}$, and $\mathrm{P}$ elements in the thoroughly cleaned aragonite crystals. Aragonite was ground into nanoparticles (Figure 4a). Mg is widely distributed within aragonite nanoparticles (Figure $4 b$ ), consistent with the distribution of Ca ions (Figure 4c), indicating that $\mathrm{Mg}$ ions can replace some $\mathrm{Ca}$ ions in aragonite lattice. In addition, the element $\mathrm{P}$ is also widely distributed in aragonite (Figure $4 \mathrm{~d}$ ), suggested that the negatively charged groups containing $\mathrm{P}$ (e.g., $\mathrm{PO}_{4}{ }^{3-}$ ) maybe were adsorbed by $\mathrm{Ca}^{2+}$ ions that led to the adulteration of $\mathrm{P}$ in the aragonite crystals. The presence of $\mathrm{P}$ and $\mathrm{Mg}$ also confirms that the formation of aragonite is closely related to the YXY2 bacteria in this study.

FTIR results of biominerals in the experimental groups are shown in Figure 5. The adsorption peaks at 712, 875, and $1421 \mathrm{~cm}^{-1}$ are the characteristic peaks of calcite-the characteristic peaks of vaterite are at 745,878 , and $1088 \mathrm{~cm}^{-1}$. Peaks at 710,856, 1084, and $1475 \mathrm{~cm}^{-1}$ indicate the presence of aragonite [5,27]. It can be seen in Figure 5 a that the adsorption peaks at 710 and 874 are the characteristic peaks of calcite and $745 \mathrm{~cm}^{-1}$ proves the presence of vaterite [27], consistent with the XRD result. The adsorption peaks at 710, 855, 877, and $1083 \mathrm{~cm}^{-1}$ indicate the co-existence of Mg-rich calcite and aragonite at $\mathrm{Mg} / \mathrm{Ca}$ ratios of 2, 4, and 6, consistent with the XRD results [5]. The peaks at 711, 857 and $1083 \mathrm{~cm}^{-1}$ reflect the presence of only aragonite at an $\mathrm{Mg} / \mathrm{Ca}$ ratio of 8 [5]. EPS secreted by YXY2 bacteria were also analyzed by FTIR, and peaks are shown in Figure $5 b$ indicate the presence of organic substances containing the following bonds: $\mathrm{C}=\mathrm{O}\left(1788 \mathrm{~cm}^{-1}\right), \mathrm{N}-\mathrm{H}\left(1550 \mathrm{~cm}^{-1}\right), \mathrm{C}-\mathrm{O}\left(1063 \mathrm{~cm}^{-1}\right)$, C-O-C (1129 and $\left.1153 \mathrm{~cm}^{-1}\right), \mathrm{P}=\mathrm{O}\left(1246 \mathrm{~cm}^{-1}\right)$, and $\mathrm{N}-\mathrm{H}\left(1550 \mathrm{~cm}^{-1}\right)$ [36]. The FTIR spectra of the supernatant that was obtained after the biominerals were processed by the ultrasonic treatment are identical with those of the sterilized distilled water, indicating that no organic substances are present within the supernatant, that is to say, the biominerals had been thoroughly cleaned (Figure 5c). Some organic substances could be detected within the thoroughly cleaned biominerals (Figure 5d), e.g., organic substances containing the chemical bonds $\mathrm{C}-\mathrm{O}, \mathrm{P}=\mathrm{O}, \mathrm{P}-\mathrm{O}, \mathrm{C}=\mathrm{O}$, and $\mathrm{C}-\mathrm{O}-\mathrm{C}$, indicating that some organic substances were involved in the biomineralization process. 

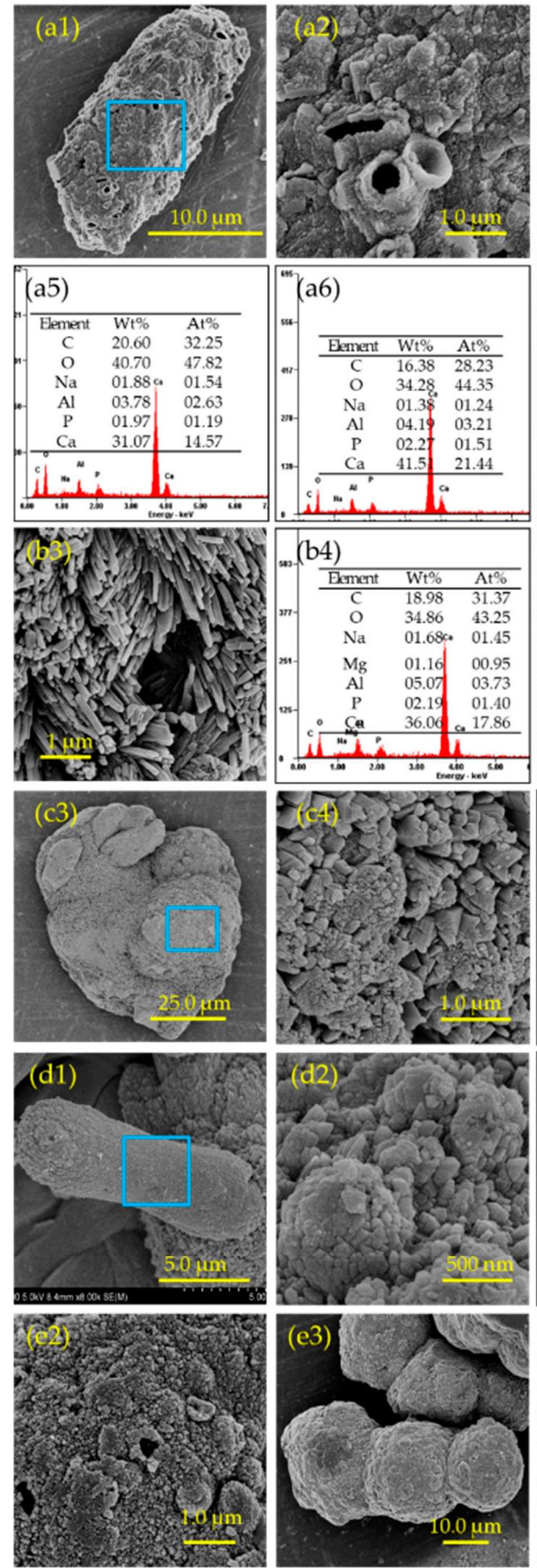
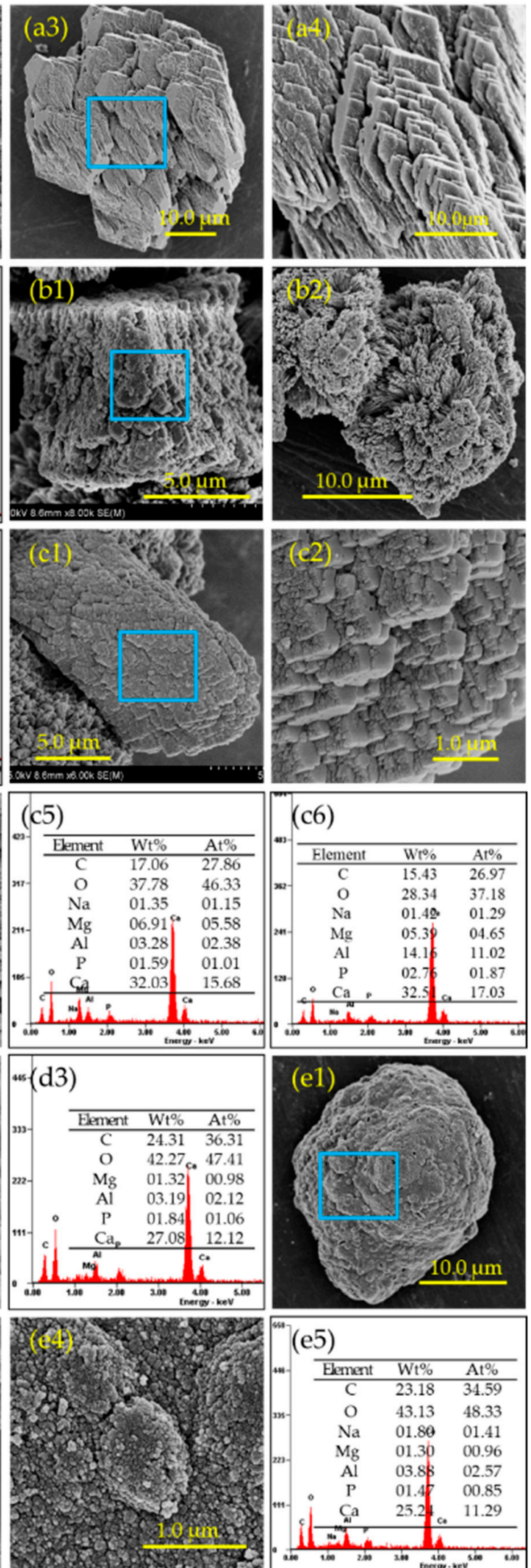

Figure 3. Scanning electron microscope (SEM) images and energy dispersive spectra (EDS) of minerals at different $\mathrm{Mg} / \mathrm{Ca}$ ratios. a1-a4, b1-b3, c1-c4, d1-d2, and e1-e4: morphologies of minerals at $\mathrm{Mg} / \mathrm{Ca}$ molar ratios of 0, 2, 4, 6 and 8, respectively. a5, a6, b4, c5, c6, d3, and e5: EDS analyses of minerals marked by blue square in a1, a3, b1, c1, c3, d1, and e1, respectively. 

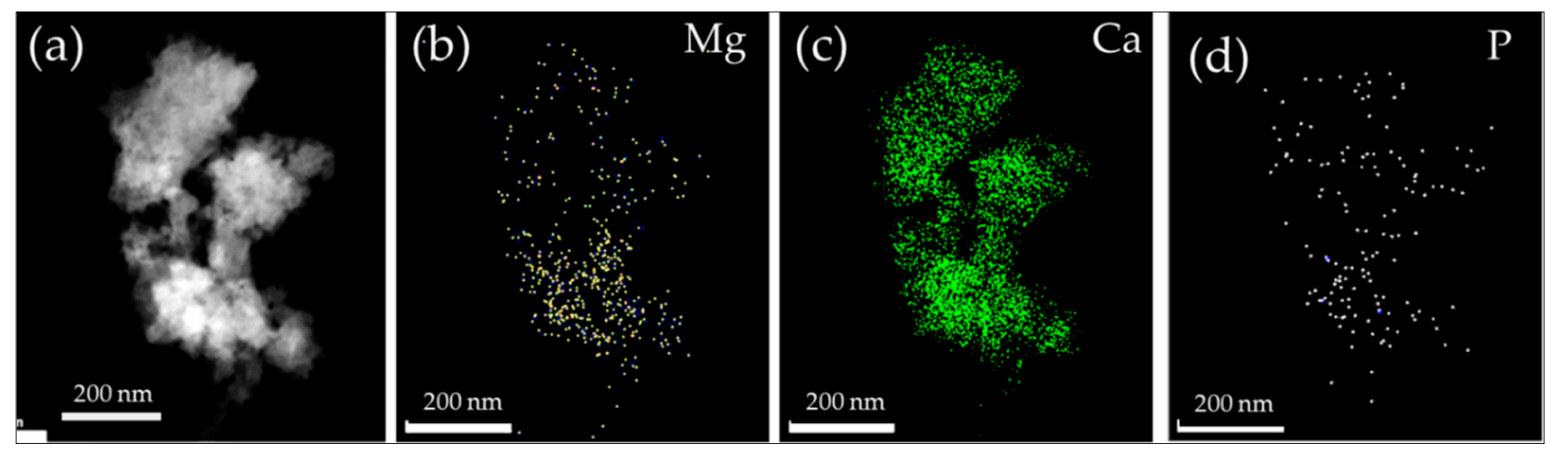

Figure 4. STEM and elemental mapping images of the biotic aragonite at a $\mathrm{Mg} / \mathrm{Ca}$ molar ratio of 8: (a) TEM image of the biotic aragonite; (b-d) $\mathrm{Mg}$, Ca, and P elements in the biotic aragonite.
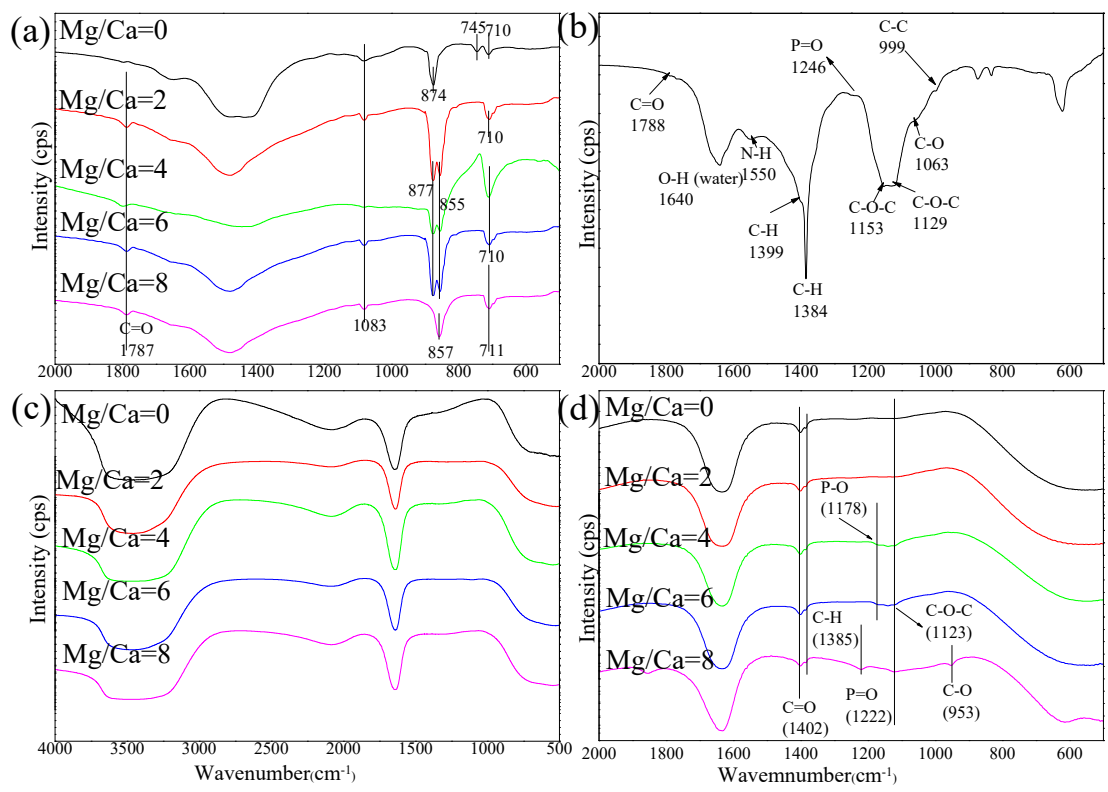

Figure 5. FTIR spectra. (a), The obtained biominerals in the experimental groups; (b), EPS of YXY2 bacteria; (c), Supernatant after the ultrasonic treatment of the biominerals; (d), Organic substances within the biominerals.

To determine the surface chemistry of the biotic aragonite, XPS was performed and the results show that the surface of the biotic aragonite contains $\mathrm{Ca}, \mathrm{C}, \mathrm{O}, \mathrm{Mg}$, and $\mathrm{P}$ (Figure 6a). For the chemically synthetized aragonite, the $\mathrm{Ca} 2 \mathrm{p}$ peaks are located at 347.9 and $351.5 \mathrm{eV}$ [37], and in the biotic aragonite, the Ca $2 p$ peaks are at 346.96 and $350.47 \mathrm{eV}$ (Figure $6 \mathrm{~b}$ ). This shift may be due to the interaction between the organic substances and calcium ions on the aragonite surface. Two peaks at 284.3 and $288.97 \mathrm{eV}$ are assigned to $\mathrm{C} 1 \mathrm{~s}$ (Figure 6c) [37]. It has been reported that the peak at $284.3 \mathrm{eV}$ is assigned to the C-C and $\mathrm{C}-\mathrm{H}$, originating from lipids or side chains of amino acid, and the peak at $288.97 \mathrm{eV}$ can be due to the $\mathrm{O}-\mathrm{C}=\mathrm{O}$ from carboxylic acid, carboxylate, or ester [38]. The $\mathrm{O} 1 \mathrm{~s}$ peak at $530.69 \mathrm{eV}$ (Figure 6d) also indicates the presence of $\mathrm{C}=\mathrm{O}$ and $\mathrm{O}-\mathrm{C}=\mathrm{O}$ from carboxylic acids, carboxylates, carbonyls and amides [26]. There was one peak at $132.78 \mathrm{eV}$ (Figure 6e) and this peak could be attributed to phosphate groups [39]. XPS results illustrate that some organic substances are present within the biotic aragonite surface, consistent with the FTIR results. These organic substances may have come from the bacteria or the metabolites released by the YXY2 bacteria. Therefore, it can be proposed that $\mathrm{YXY} 2$ bacteria played an important role in the biomineralization process. 

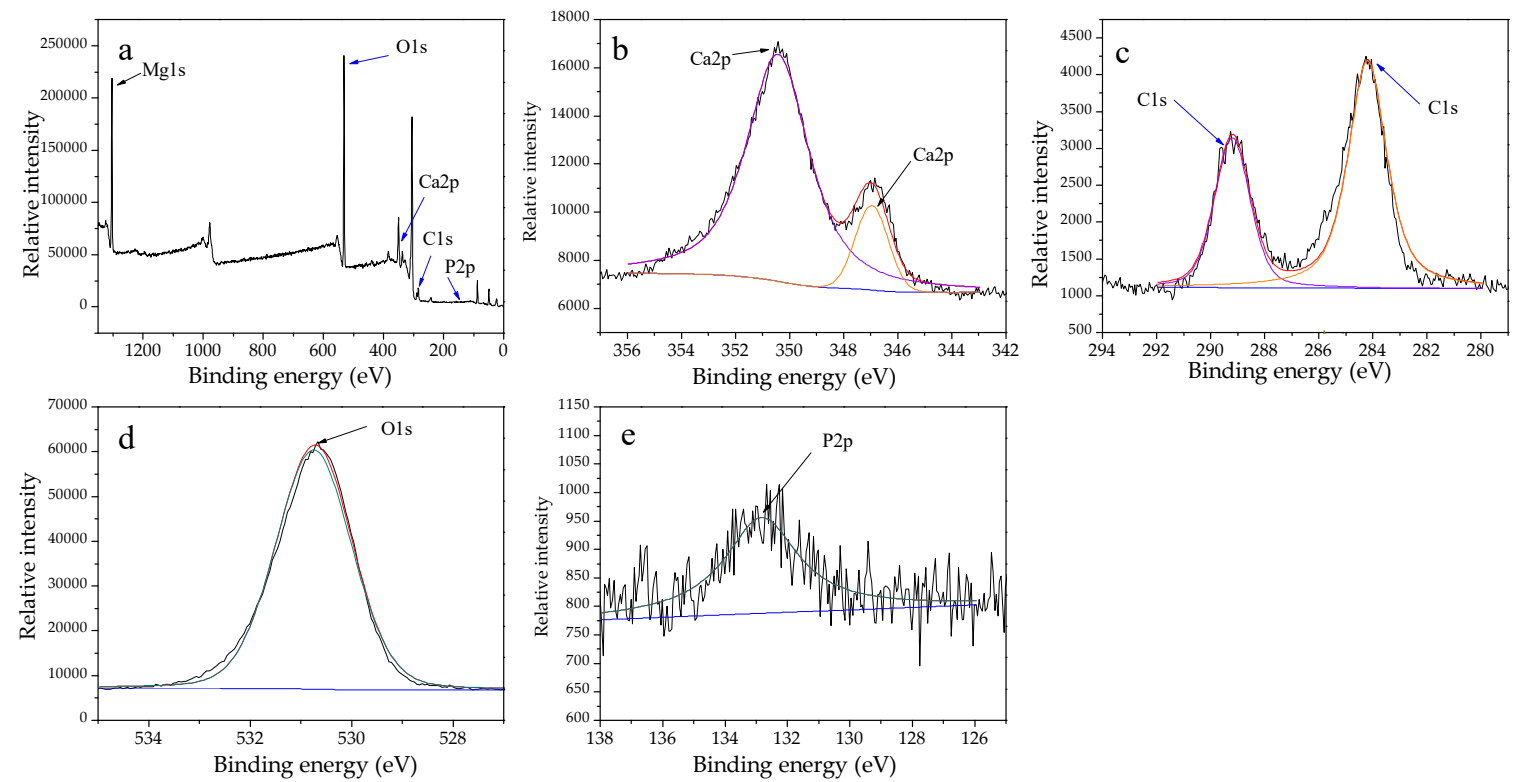

Figure 6. XPS results of the biotic aragonite at $\mathrm{Mg} / \mathrm{Ca}$ ratio of 8 . XPS spectrum of aragonite surface (a) and the Ca 2p (b), C 1s (c), O 1s (d), and P 2p (e) spectra.

To further prove that it was the YXY2 bacterium that induced the formation of these minerals, the stable carbon isotope values of these biominerals were analyzed. The stable carbon isotope values $\delta^{13} \mathrm{C}_{\mathrm{PDB}}(\%$ o $)$ of the biotic minerals at various $\mathrm{Mg} / \mathrm{Ca}$ ratios $(-17.93 \%$ o and $-15.27 \%$ ) are much more negative than those of the abiotic minerals $(-11.19 \%$ ond $-12.41 \%$ o) (Table 1$)$. The stable carbon isotope values $\delta^{13}$ of the organic substances are $18.86 \%$ ond $-21.56 \%$, respectively, and the $\delta^{13} \mathrm{C}_{\mathrm{PDB}}$ (\%o) value of the atmospheric $\mathrm{CO}_{2}$ is $-8 \%$ o $[12,16,26]$. The stable carbon isotope values of the biotic minerals are much closer to those of the organic substances rather than $\mathrm{CO}_{2}$. Thus, it can be concluded that carbon in the biominerals was mainly derived from organic substances rather than atmospheric $\mathrm{CO}_{2}$. The more negative stable carbon isotope values further proved the biogenesis of these carbonate minerals. The organic substances in the culture medium could be as the nitrogen and carbon sources, which were then used in microbial metabolism; after the degradation by YXY2 bacteria, a certain amount of $\mathrm{NH}_{3}$ and $\mathrm{CO}_{2}$ could be released. The released $\mathrm{NH}_{3}$ could lead to an increase in $\mathrm{pH}$ [16], resulting in an alkaline condition; and in this alkaline condition, $\mathrm{CO}_{2}$ could be converted into carbonate and bicarbonate ions through the hydration reaction catalyzed by $\mathrm{CA}$, which not only increased $\mathrm{pH}$ but also promoted the oversaturation that contributed to the precipitation of calcium carbonate minerals. Thus, much of the carbon in the biominerals came from $\mathrm{CO}_{2}$ produced by microbial metabolism, which made the stable carbon isotope values become more negative.

Table 1. Stable carbon isotope values $\delta^{13} \mathrm{C}_{\mathrm{PDB}}(\%$ ) of the biotic and abiotic minerals and the organic substances.

\begin{tabular}{cccccc}
\hline \multirow{2}{*}{ Mg/Ca Ratios } & \multirow{2}{*}{ Biotic Minerals } & \multicolumn{2}{c}{ Abiotic Minerals } & \multicolumn{2}{c}{ Organic Carbon Source } \\
\cline { 3 - 5 } & & Calcite & Aragonite & Beef Extract & Tryptone \\
\hline 0 & -15.27 & & & & \\
2 & -16.47 & & & & \\
4 & -17.01 & -11.19 & -12.41 & -18.86 & -21.56 \\
6 & -17.45 & & & & \\
8 & -17.93 & & & & \\
\hline
\end{tabular}

The thermal characteristics of the biotic and abiotic aragonite were analyzed by TG, DTG, and DSC, and the results are shown in Figure 7. As shown in Figure 7a, there are mainly three mass loss steps: The first step was at about $100{ }^{\circ} \mathrm{C}$, indicating the loss of chemically bound water and 
structural water; the second weight-loss stage was in the temperature range of $300-400{ }^{\circ} \mathrm{C}$, suggesting the decomposition of organic matter within aragonite crystals; the third stage was the main mass loss phase, which took place at about $700{ }^{\circ} \mathrm{C}$, corresponding to the decomposition of aragonite to release carbon dioxide (Equation (1)).

$$
\mathrm{CaCO}_{3} \rightarrow \mathrm{CaO}+\mathrm{CO}_{2} \uparrow
$$
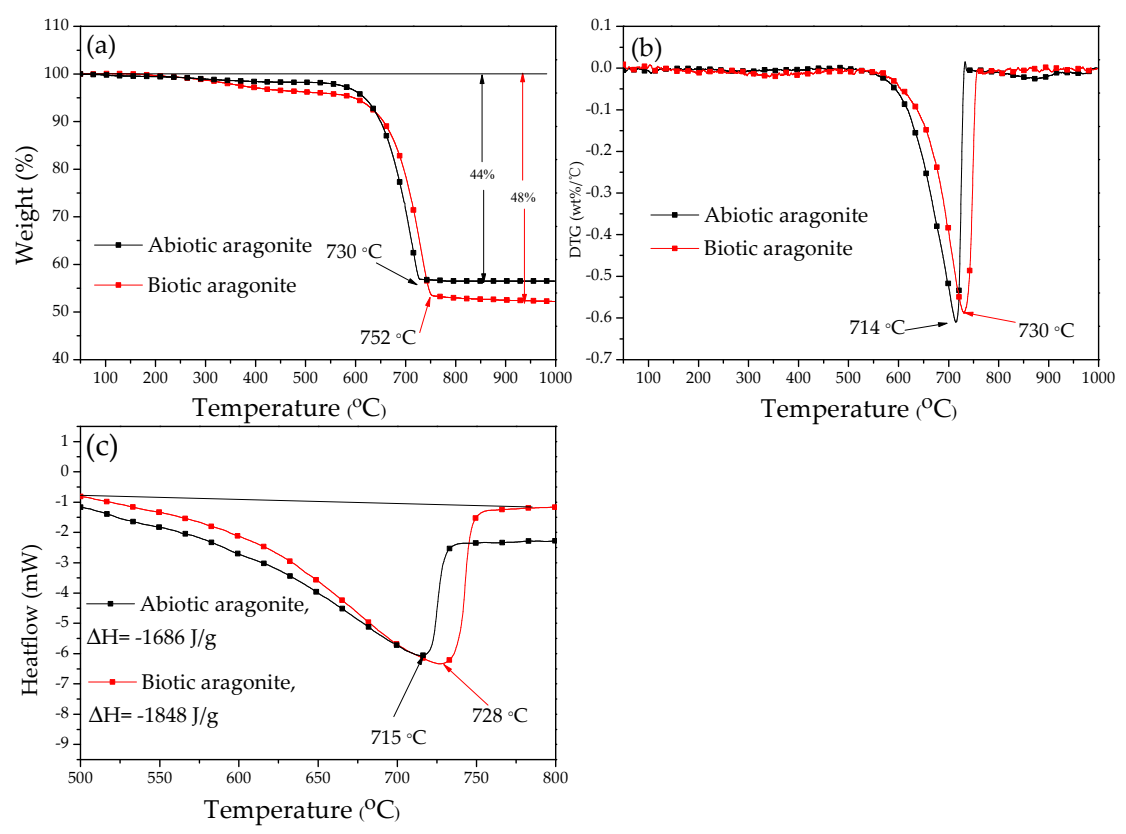

Temperature $\left({ }^{\circ} \mathrm{C}\right)$

Figure 7. TG
$10^{\circ} \mathrm{C} \min ^{-1}$.

DTG curves (Figure $7 \mathrm{~b}$ ) show that the final decomposition temperature of the abiotic aragonite was $714^{\circ} \mathrm{C}$, lower than that of the biotic aragonite $\left(730^{\circ} \mathrm{C}\right)$, indicating that the biotic aragonite had higher thermal stability than the abiotic aragonite. Table S2 reveals that the biotic aragonite had higher crystallinity than the abiotic aragonite, resulting in the fact that the biotic aragonite had a higher thermal stability. DSC results of the abiotic and biotic aragonite are shown in Figure 7c. The enthalpy changes $(\Delta \mathrm{H})$ of the abiotic and biotic aragonite were -1686 and $-1848 \mathrm{~J} / \mathrm{g}$, respectively, which indicate that more energy was needed to decompose the biotic aragonite than the abiotic aragonite. The peak temperature of the biotic aragonite was $728{ }^{\circ} \mathrm{C}$, higher than that of the abiotic aragonite $\left(715^{\circ} \mathrm{C}\right)$ (Figure $\left.7 \mathrm{c}\right)$, also revealing the higher thermal stability of the biotic aragonite than the abiotic aragonite. Thus, it can be concluded that the thermal stability of the biotic aragonite increased due to the participation of the YXY2 bacteria.

\subsection{Intracellular Biomineralization Induced by S. Warneri YXY2 Bacteria}

As shown in Figure 8, YXY2 bacteria without staining Fluo-3 AM did not emit green fluorescence, further proving that YXY2 bacteria could not emit green fluorescence by themselves; but those stained with Fluo-3 AM did emit green fluorescence, indicating that $\mathrm{Ca}^{2+}$ ions were present inside the cells. YXY2 bacteria cultured in the medium without any $\mathrm{Ca}^{2+}$ and $\mathrm{Mg}^{2+}$ ions, namely the bacterial seeds, were also stained by Fluo-3 AM, and the result showed that the green fluorescence could not be observed, suggesting that the concentration of intracellular $\mathrm{Ca}^{2+}$ was too low to be measured. That is to say, in the presence of $\mathrm{Ca}^{2+}$ ions, $\mathrm{Ca}^{2+}$ ions can enter the YXY2 bacterial cells. In addition, with increasing $\mathrm{Mg} / \mathrm{Ca}$ ratios, the average fluorescence intensities of $\mathrm{Ca}^{2+}$ ions became weaker. Thus, in our opinion, the presence of $\mathrm{Mg}^{2+}$ ions do influence the entry of $\mathrm{Ca}^{2+}$ into cells, causing the decline of intracellular $\mathrm{Ca}^{2+}$ concentration. 


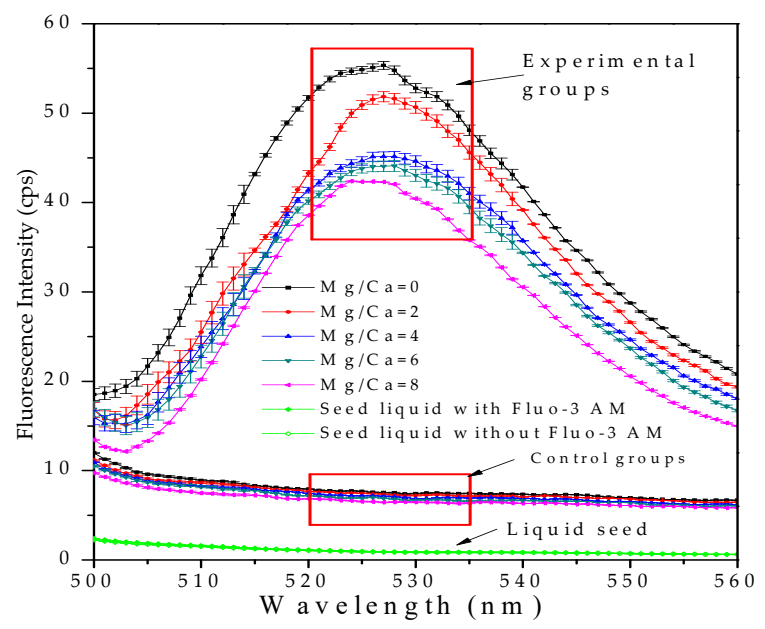

Figure 8. Fluorescence intensities of intracellular $\mathrm{Ca}^{2+}$ ions at various $\mathrm{Mg} / \mathrm{Ca}$ ratios.

HRTEM images of the ultrathin slices of YXY2 bacteria (Figure 9) show that nano-scaled dark inclusions are present inside the cells in the experimental groups at $\mathrm{Mg} / \mathrm{Ca}$ ratios of 0 and 8 (blue square in Figure 9a1,b1), and are also present in the EPS (blue square in Figure 9a2,b2). However, no inclusions were observed in the bacterial cells in the liquid medium without $\mathrm{Mg}^{2+}$ and $\mathrm{Ca}^{2+}$ ions (Figure 9c1,2). The elemental composition analyses of the dark inclusions (in Figure 9a1,b1) show that Ca is present (Figure 9a3,b3). Thus, the cells in the mediums with $\mathrm{Ca}^{2+}$ and $\mathrm{Mg}^{2+}$ ions are different from those in the mediums without any $\mathrm{Ca}^{2+}$ and $\mathrm{Mg}^{2+}$ ions, and the important point is that $\mathrm{Ca}^{2+}$ and $\mathrm{Mg}^{2+}$ ions can enter the cells, consistent with the results of the intracellular fluorescence intensity of $\mathrm{Ca}^{2+}$ ions (Figure 8). From the SAED images, no diffraction spots or diffraction rings were observed, indicating that no crystalline structures are present in these inclusions (Figure 9a1,b1). The dark inclusion in the EPS (Figure 9a2) has a poor crystalline structure due to the presence of the diffraction spots in the inset of Figure 9a2, indicating that EPS could be the nucleation site for the formation of these biominerals. The elemental mapping of bacteria (Figure 10) also shows the distribution of $\mathrm{Ca}^{2+}$ and $\mathrm{Mg}^{2+}$ inside the cells. In the experimental groups, not only $\mathrm{Ca}$ but also $\mathrm{Mg}$ was detected, and these ions are distributed inside the cells and EPS (Figure 10), further proving that these ions can enter into the cell through the EPS. It is noteworthy that the distribution of $\mathrm{Ca}$ and $\mathrm{Mg}$ is consistent with the dark inclusions (Figure 10), indicating that the dark inclusions contain $\mathrm{Ca}$ and/or Mg elements.
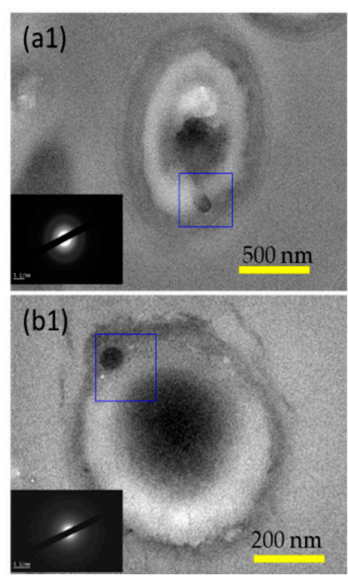
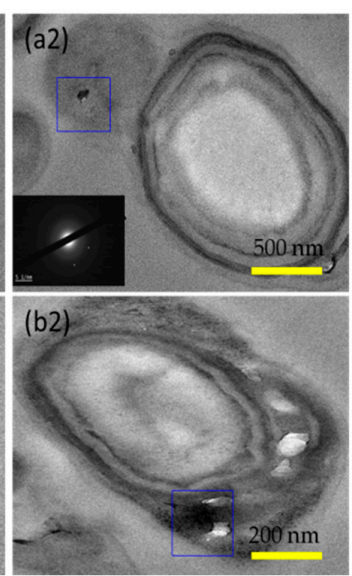
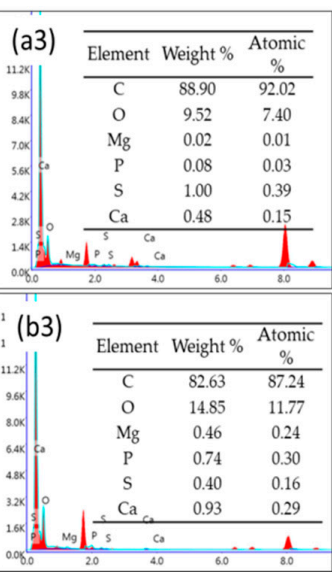

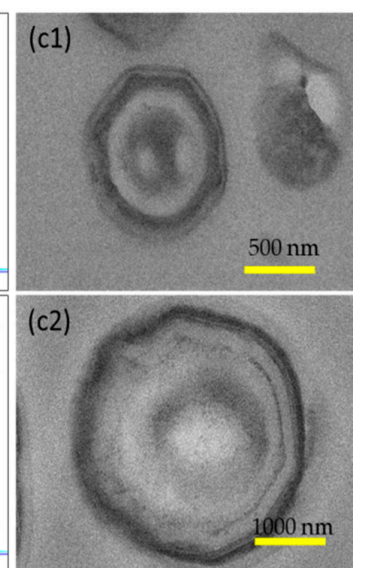

Figure 9. HRTEM images of the ultrathin slices of $S$. warneri $Y X Y 2$ cells cultivated for 14 days (a1,a2): cells in the experimental group at $\mathrm{Mg} / \mathrm{Ca}$ ratio of 0 ; a3: EDS analysis of the dark inclusion marked by the blue square in a1; (b1,b2): cells in the experimental group at $\mathrm{Mg} / \mathrm{Ca}$ ratio of 8 ; b3: analysis of the dark inclusion marked by the blue square in b1; (c1,c2): cells in the medium without any $\mathrm{Ca}^{2+}$ and $\mathrm{Mg}^{2+}$ ions). 

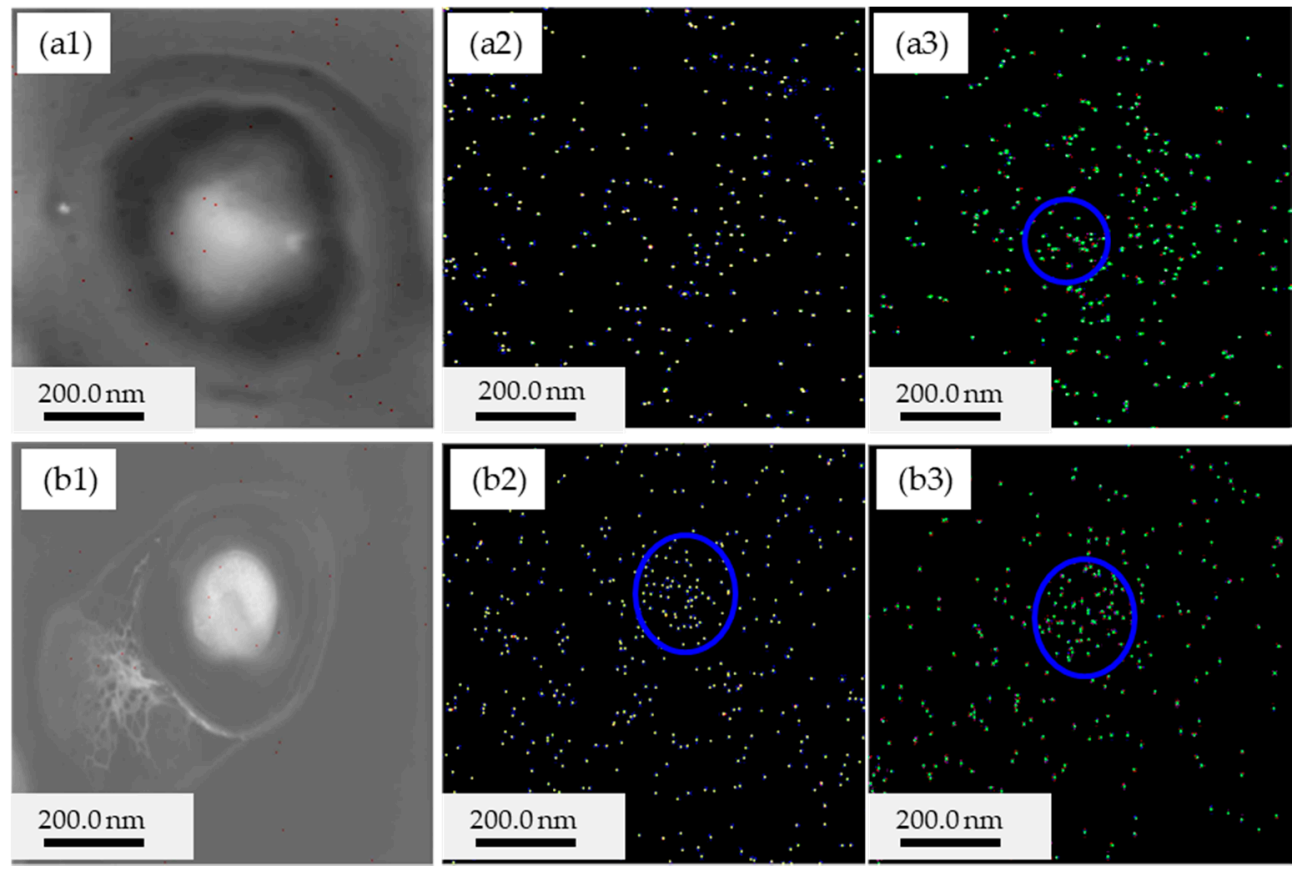

Figure 10. Elemental maps of the ultrathin slices of YXY2 bacterium cultivated for 14 days (a1), STEM images of cells in the experimental group at an $\mathrm{Mg} / \mathrm{Ca}$ molar ratio of 0 ; (a2,a3), elemental mapping of $\mathrm{Mg}$ and $\mathrm{Ca}$, respectively; (b1), STEM image of cells in the experimental group at a $\mathrm{Mg} / \mathrm{Ca}$ molar ratio of 8; (b2,b3), mapping images of $\mathrm{Mg}$ and $\mathrm{Ca}$, respectively.

\subsection{Amino Acid Composition of EPS}

The amino acid composition of EPS secreted by YXY2 bacteria is shown in Figure 11. Seventeen kinds of amino acids were detected. Among these amino acids, glutamic acid (Glu) was the most abundant one, followed by glycine (Gly) and aspartic acid (Asp). Most of the amino acids were negatively charged due to the deprotonation in an alkaline condition, except for lysine (Lys) and arginine (Arg). Of note is that the amino acid composition of the organic substances within the biotic aragonite (Figure 11) is almost identical with that of EPS secreted by the YXY2 bacteria, suggesting that EPS may participate in the formation process of the biotic aragonite.

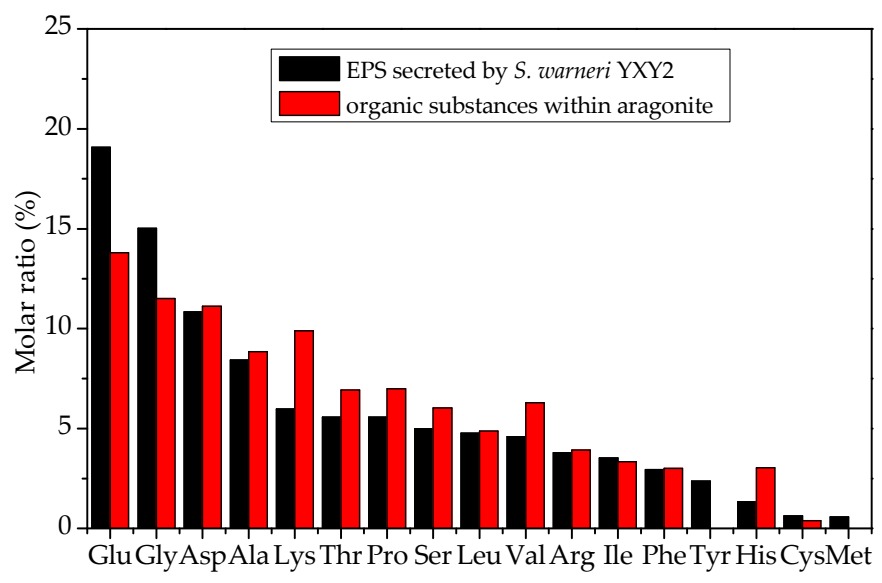

Figure 11. Amino acid composition of EPS secreted by YXY2 bacterium and that of the organic substances within the biotic aragonite minerals. 


\subsection{Molecular Dynamics Simulation}

Glutamic acid was chosen because it was the most abundant amino acid in the EPS. Firstly, a dynamic model of aragonite and a model of Glu was constructed (Figure 12a,b). Then, the selective adsorption of Glu onto various crystal planes was undertaken and the adsorption energies were calculated. The parameters are given in Table S3. The adsorption energies of Glu adsorbed onto various aragonite crystal planes were obtained according to Equation (2):

$$
E_{\text {adsorption }}=E_{\text {total }}-\left(E_{\text {Glu }}+E_{\text {surface }}\right)
$$

where $E_{\text {total }}$ is the energy of total system, $E_{\text {surface }}$ is the single point energy of one aragonite plane, $E_{G l u}$ is the single point energy of the Glu molecule after dynamic simulation. The dynamic models of the (111) planes before and after adsorption (Figure 12c,d) show that Glu was much closer to the aragonite surface after adsorption.
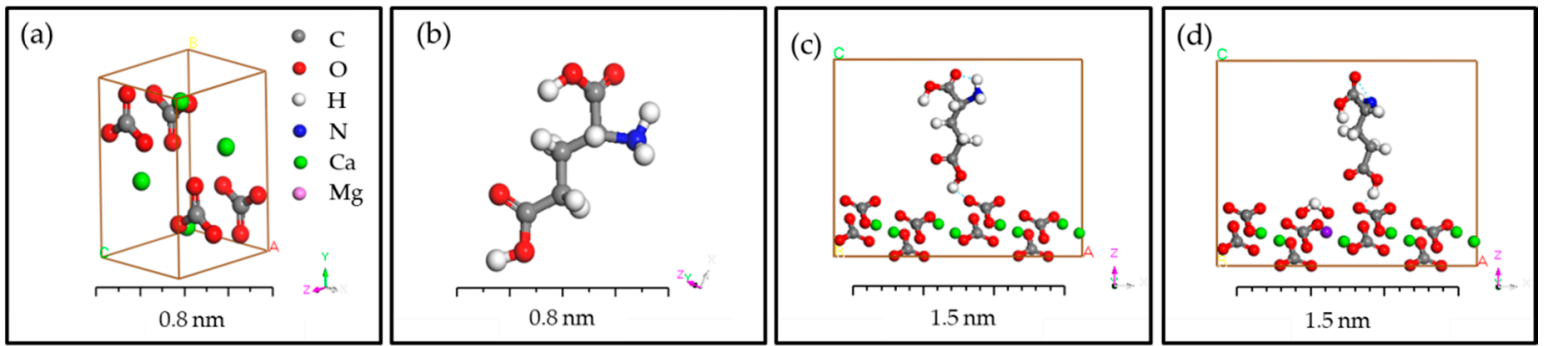

Figure 12. Simulation project of adsorption of Glu onto an aragonite crystal. (a) the 3D graph of aragonite crystal; (b) the molecular structure of Glu; (c) the configuration before adsorption of Glu onto the (011) face of aragonite; (d) the configuration after adsorption of Glu onto the (011) face of aragonite.

The adsorption energies of the Glu molecule adsorbed onto different crystal planes were different, suggesting the diverse affinity of the Glu molecule for different aragonite crystal planes (Table 2). Previous research has shown that Glu has an inhibition effect on crystal growth [40]. Thus, selective adsorption of the Glu molecule onto various crystal planes indicates the different inhibition effects on the growth rates of those planes. The diffraction intensity of the (221) crystal plane of aragonite was higher than that of (012), revealing the occurrence of the preferred orientation (Figure 2), which was mainly due to the different effects of organic matter on the (221) and (012) crystal planes.

Table 2. The interaction energy between Glu and various aragonite crystal planes ( $\mathrm{kcal} / \mathrm{mol})$.

\begin{tabular}{ccccc}
\hline Surfaces & $\mathbf{( 1 1 1 )}$ & $\mathbf{( 2 2 1 )}$ & $\mathbf{( 0 1 2 )}$ & $\mathbf{( 0 2 1 )}$ \\
\hline $\mathrm{E}_{\text {total }}$ & $747,500.50$ & $369,6261.00$ & $481,336.50$ & $696,041.50$ \\
$\mathrm{E}_{\text {surface }}$ & 214.16 & 140.70 & 66.39 & 73.27 \\
$\mathrm{E}_{\text {Glu }}$ & $749,137.00$ & $369,7010.00$ & $481,873.00$ & $696,442.00$ \\
$\mathrm{E}_{\text {adsorption }}$ & -1850.66 & -889.70 & -602.89 & -473.77 \\
\hline
\end{tabular}

\section{Discussion}

\subsection{S. Warneri YXY2 Creating the Suitable Conditions for Biomineralization}

A large number of papers have demonstrated the important role played by microorganisms on changes of the microenvironment in the biomineralization process [5,6], and these changes include the $\mathrm{pH}$, ionic strength, medium viscosity, and so on. Among these factors, $\mathrm{pH}$ has been regarded as one of the most important parameters regulating mineral precipitation. Many researchers have concluded that the reason for $\mathrm{pH}$ increase is the ammonia released by bacteria [41,42]. For example, peptone, as one component of the culture medium, is abundant in the amino acids that can be used by bacteria to 
release ammonia. Ammonia will dissolve in water quickly to produce ammonium and free hydroxyl groups (Equation (3)), leading to an increase in $\mathrm{pH}$.

$$
\mathrm{NH}_{3}+\mathrm{H}_{2} \mathrm{O} \rightarrow \mathrm{NH}_{4}^{+}+\mathrm{OH}^{-}
$$

This is the consensus. However, recently, Han et al. [9,27,29] and Zhuang et al. [16] have demonstrated that the $\mathrm{pH}$ increase is a more complicated problem and the cause is not just ammonia. In this light, researchers still need to explore the issue in depth.

In this study, the concentration of $\mathrm{NH}_{4}^{+}$was measured, and it was found that $\mathrm{pH}$ based on the concentration of $\mathrm{NH}_{4}^{+}$(8.22) was much lower than that of the experimental group ( $\mathrm{pH}$ 8.65, Figure 1a). This demonstrates that the released ammonia is unable to increase $\mathrm{pH}$ beyond 8.65. So, what other factors could cause $\mathrm{pH}$ to rise besides ammonia? Whether ALP and CA activities also increase $\mathrm{pH}$ is a question that few people have discussed.

ALP, an enzyme located on the external cell membrane, can dephosphorylate from many organic substrates containing the phosphate group. That is to say, under the catalysis of ALP, the phosphate group can be removed from the substrate molecule, which can result in the production of the hydrogen phosphate ion $\left(\mathrm{HPO}_{4}{ }^{2-}\right)$ and hydroxyl groups $\left(\mathrm{OH}^{-}\right)$that leads to a $\mathrm{pH}$ increase. A pH curve based on the concentration of phosphate can be obtained (Figure 1a) and the $\mathrm{pH}$ value is far greater than that of the experimental group. The phosphate content produced via ALP also contributes to the $\mathrm{pH}$ increase. Thus, ALP released by $S$. warneri $\mathrm{YXY} 2$ should also be considered as one of the reasons for $\mathrm{pH}$ increase.

The important roles played by CA released from the bacteria have also been investigated in many studies $[5,35,43]$. The hydration reaction of $\mathrm{CO}_{2}$ (Equation (4)) will be significantly improved with the catalysis of $\mathrm{CA}$, and it has been reported that the catalytic constants $\mathrm{k}_{\mathrm{cat}}$ are in the range of 3.9 to $8.0 \times$ $10^{5} \mathrm{~s}^{-1}$ and the kinetic efficiencies $\mathrm{k}_{\mathrm{cat}} / \mathrm{K}_{\mathrm{m}}$ are in the range of 4.3 to $9.7 \times 10^{7} \mathrm{M}^{-1} \mathrm{~s}^{-1}$ [44]. Bicarbonate will then react with the hydroxyl group $\left(\mathrm{OH}^{-}\right)$to produce the carbonate ions (Equation (5)).

$$
\begin{gathered}
\mathrm{CO}_{2}+\mathrm{H}_{2} \mathrm{O} \rightarrow \mathrm{H}_{2} \mathrm{CO}_{3} \rightarrow \mathrm{HCO}_{3}^{-}+\mathrm{H}^{+} \\
\mathrm{HCO}_{3}^{-}+\mathrm{OH}^{-} \rightarrow \mathrm{CO}_{3}^{2-}+\mathrm{H}_{2} \mathrm{O}
\end{gathered}
$$

$\mathrm{pH}$ values based on the concentrations of bicarbonate and carbonate ions were obtained (Figure 1a), which were much higher than those of the culture medium inoculated with S. warneri YXY2. That is to say, bicarbonate and carbonate ions produced under the catalytic reaction of CA also resulted in a $\mathrm{pH}$ increase.

Therefore, the $\mathrm{pH}$ increase in this study was the result of the combined effects of ammonia, ALP and CA released by $S$. warneri YXY2 bacteria. CA does not only lead to a $\mathrm{pH}$ increase but also promotes the production of bicarbonate and carbonate ions; therefore, supersaturation of Ca-carbonate minerals was attained. Bicarbonate and carbonate ions will react with $\mathrm{Ca}^{2+}$ ions in the alkaline environment, and then the bio-precipitation of carbonate minerals will occur according to the following Equation (6):

$$
\mathrm{CO}_{3}^{2-}+\mathrm{HCO}_{3}^{-}+2 \mathrm{Ca}^{2+}+\mathrm{OH}^{-} \rightarrow 2 \mathrm{CaCO}_{3} \downarrow+\mathrm{H}_{2} \mathrm{O}
$$

In brief, S. warneri YXY2 bacteria play an important role in the biomineralization process, which is proved by the absence of minerals in the control groups not inoculated with $S$. warneri YXY2.

\subsection{EPS Serving as the Nucleation Site and the Preferred Orientation of Aragonite}

The presence of diffraction spots in the SAED spectrum (Figure 9a2) reveals that the nano-sized particles in the EPS have a crystalline structure, indicating that EPS provides the nucleation sites for the formation of carbonate minerals. Figure $9 \mathrm{~b} 2$ also shows that the EPS act as the nucleation sites. The nanometer-sized minerals are probably aragonite according to the mineral phase at an $\mathrm{Mg} / \mathrm{Ca}$ molar ratio of 8 in the $\mathrm{XRD}$ results, which is just in the early growth stage. 
Special molecular interaction at the inorganic-organic interface can control the nucleation and growth of inorganic crystals [45]. Many researchers have accepted the opinion that EPS plays an important role in the biomineralization process $[5,13,29]$. Bains et al. have also found that the content of EPS secreted by Bacillus megaterium SS3 can affect the precipitation of carbonate, which may be due to the fact that EPS has the strong adsorption capacity for cations and can act as the nucleation site [46]. However, how to nucleate in/on the EPS is a question needed to be further explored. According to the rule that the function depends on the structure, the amino acid composition in the EPS of YXY2 bacteria has been further studied. In this study, most amino acids were negatively charged due to deprotonation in alkaline conditions, which make amino acids adsorb more $\mathrm{Ca}^{2+}$ and $\mathrm{Mg}^{2+}$ ions. The elemental mapping image of YXY2 bacteria also shows the presence of abundant $\mathrm{Ca}^{2+}$ and $\mathrm{Mg}^{2+}$ in the EPS (Figure 10), confirming that the EPS can adsorb a large number of cations that would promote the nucleation of minerals. Besides, the amino acids within the minerals were identical with those in the EPS (Figure 11), which further confirms that the formation of these biominerals had a close relationship with the EPS. There is presently a consensus that the presence of organic substance facilitates a reduction in the nucleation activation energy $(\Delta G)$ [45]. In this study, EPS may also have the same effect to decrease the active energy of nucleation.

XRD analysis of the aragonite of eggshells of Testudines (turtles) shows that the (001) crystal plane has a preferred orientation [47]. Hou and Feng investigated the tablets of nacre and found that the protein sheets affected the growth of aragonite, which could be used to interpret the preferred orientation [48]. In this study, the phenomenon of preferred orientation is obvious from the XRD pattern (Figure 2) although its reason is still not clear. Amino acids were detected within aragonite crystals and their composition was nearly identical with that of EPS. Thus, in our opinion, EPS, especially the amino acids in the EPS, may be one of the main reasons for the preferred orientation of crystal planes in aragonite.

Adsorption energies of the Glu molecule onto different crystal planes of aragonite were different, suggesting the diverse affinity of the Glu molecule for different aragonite planes (Table 2). Thus, selective adsorption of the Glu molecule onto various planes could lead to the different inhibition on the growth rates of those planes. The peak of the (221) with its higher intensity suggests that Glu may preferentially be adsorbed onto that plane, rather than the plane (012), ultimately impeding the growth rate of the plane (221). Thus, plane (012) with its higher growth rate would develop poorly, maybe disappearing eventually. This is the main reason for the preferred orientation in the (221) crystal plane. According to the simulation results (Table 2), the adsorption ability of the (221) to Glu was stronger than (012), indicating that Glu had a stronger inhibition effect on the growth of plane (221) than plane (012); this result also confirms our hypothesis.

\subsection{The Role of $\mathrm{Mg} / \mathrm{Ca}$ Molar Ratios in Calcium Carbonate Polymorphs}

The hypothesis that the $\mathrm{Mg} / \mathrm{Ca}$ ratio significantly control calcium carbonate polymorphs has been widely accepted. In this research, the dominant mineral was aragonite in the presence of $\mathrm{Mg}^{2+}$ ions, however, no aragonite was precipitated in the absence of $\mathrm{Mg}^{2+}$ ions, consistent with previous opinions. The weight percent of aragonite increased with increasing $\mathrm{Mg} / \mathrm{Ca}$ molar ratios. Therefore, $\mathrm{Mg}^{2+}$ is considered as an important regulator of $\mathrm{CaCO}_{3}$ polymorphs [49]. It is generally believed that a higher concentration of $\mathrm{Mg}^{2+}$ ions in solution can inhibit the formation of a calcite nucleus and promote the growth of an aragonite nucleus because $\mathrm{Mg}^{2+}$ ions inhibit the growth of calcite through entering into the calcite lattice and changing the thermodynamic properties of its new growth surface [49]. In this study, in the culture medium inoculated with YXY2 bacteria, calcite and vaterite were the predominant minerals at an $\mathrm{Mg} / \mathrm{Ca}$ molar ratio of 0 ; aragonite was the only mineral phase at an $\mathrm{Mg} / \mathrm{Ca}$ ratio of 8 (Figure 2), clearly indicating that $\mathrm{Mg}^{2+}$ ions play an important role in controlling the Ca-carbonate polymorphs. It should be noted that only $\mathrm{Mg}$-rich calcite formed at an $\mathrm{Mg} / \mathrm{Ca}$ molar ratio $\leq 2$ in other studies [1,2]; however, the co-precipitation of $\mathrm{Mg}$-rich calcite and aragonite occurred at an $\mathrm{Mg} / \mathrm{Ca}$ ratio of 2 in this study. That is to say, precipitation of aragonite did occur at lower $\mathrm{Mg} / \mathrm{Ca}$ ratios in this 
study. In our opinion, YXY2 bacteria or metabolites may be another important control of Ca-carbonate polymorphs in some cases.

As for the $\mathrm{Mg} / \mathrm{Ca}$ molar ratios, they were indeed crucial to the transformation of calcium carbonate polymorphs. The halophiles Staphylococcus epidermis Y2 and Chromohalobacter israelensis LD532 were also used to induce the precipitation of carbonate minerals at $\mathrm{Mg} / \mathrm{Ca}$ molar ratios of $0,2,4,6$ and 8, and the results showed that the minerals induced by these two species of bacteria were monohydrocalcite minerals at $\mathrm{Mg} / \mathrm{Ca}$ molar ratios of 4, 6, and 8 [9]. In our study, halophile Staphylococcus warneri YXY2 bacteria was used to induce the biomineralization and the results show that aragonite minerals were obtained at $\mathrm{Mg} / \mathrm{Ca}$ molar ratios of 4,6 , and 8 , but not monohydrocalcite. Why was there a difference in the mineral phases at the same $\mathrm{Mg} / \mathrm{Ca}$ molar ratios, at the same salinity $(10 \%)$ ? It was the bacterium. That is to say, different species of bacteria can induce different kinds of minerals even if at the same $\mathrm{Mg} / \mathrm{Ca}$ molar ratios, directly illustrating that it is the biological factors that play the important role in the transition of monohydrocalcite/aragonite, as well as the $\mathrm{Mg} / \mathrm{Ca}$ molar ratios. If $\mathrm{Mg}^{2+}$ ions were not present in the culture system, would aragonite still be obtained? Zhou et al. have performed experiments to prepare highly organized aragonite rods over a broad range of $\mathrm{pH}$ values (1.5-6.9), and the results indicated that even without the presence of $\mathrm{Mg}^{2+}$ ions, aragonite minerals could still be obtained [32]. Therefore, the precipitation of aragonite was not necessarily in an environment where $\mathrm{Mg}^{2+}$ ions were present. All these pieces of evidence were proving that in certain conditions, microorganisms, especially the bacterial species, played a significant role in the transition of minerals, in addition to the $\mathrm{Mg} / \mathrm{Ca}$ molar ratios.

Some acidic macromolecules extracted from living organisms have already been found to have the ability to affect the formation of aragonite. Soluble proteins with different molecular weights were isolated from the pearl layer in an abalone shell, and among these, some specific components were found to have the ability to induce aragonite crystals [3]. In our study, amino acids are present within the biotic aragonite (Figure 12) and FTIR results show that some organic substances were present within aragonite minerals, demonstrating the close relationship between minerals and organic substances. These all support our opinion that metabolites released by YXY2 bacteria may favor aragonite formation. Therefore, calcium carbonate polymorphs may be regulated by some organic molecules. The mechanism inducing calcium carbonate polymorphs needs to be further studied.

\subsection{Possible Mechanism of $\mathrm{Mg}$ Entry into the Biotic Aragonite}

It is generally accepted that $\mathrm{Mg}^{2+}$ ions can enter into the calcite lattice, leading to the formation of magnesian calcite, whereas $\mathrm{Mg}^{2+}$ ions cannot enter into the dense aragonite lattice [50]. However, $\mathrm{Mg}^{2+}$ ions have been detected in the biotic aragonite of coral skeletons, foraminifera, and other organisms [4,50,51]. For instance, the amount of $\mathrm{Mg}^{2+}$ in coral aragonite is about $0.49 \mathrm{~mol} \%$ [4]. However, the entry mode and location of the $\mathrm{Mg}^{2+}$ ions in biological aragonite have not been clarified. Flinch and Allison proposed that $\mathrm{Mg}^{2+}$ ions in biological aragonite did not replace $\mathrm{Ca}^{2+}$ ions in the lattice but were present in organic matter (such as magnesium acetate) or in an inorganic amorphous phase (such as amorphous carbonate, magnesium carbonate or hydroxide) [52]. Meibom et al. suggested that the significant change of $\mathrm{Mg}^{2+}$ content in coral fibrous aragonite is not related to the external marine environment, but closely related to the biological activity of the coral itself [53]. Meibom et al. also found that the $\mathrm{Mg} / \mathrm{Ca}$ ratio in corals with symbiotic zooxanthellae was significantly higher than that in non-zooxanthellate corals. This may be due to the fact that the zooxanthellae affect the composition of protein and soluble organic matter in the coral during the formation of its skeleton [53]. Other researchers have suggested that $\mathrm{Mg}^{2+}$ ions in biological aragonite have substituted for $\mathrm{Ca}^{2+}$ ions [54] or been adsorbed onto aragonite surfaces [55].

In this study, the Mg content (Figure S4) and EDS results (Figure 3) show that $\mathrm{Mg}^{2+}$ ions were present in the biotic aragonite whereas they were absent in the abiotic aragonite. The STEM image of the biotic aragonite nanoparticles (Figure 4) also suggests that $\mathrm{Mg}^{2+}$ ions were distributed within the biotic aragonite, which indicates that $\mathrm{Mg}^{2+}$ can enter into the aragonite crystal lattice rather than be adsorbed 
onto the aragonite surface. FTIR and XPS results (Figures 5 and 6) indicate there were some organic substances within the aragonite. The amino acid composition results (Figure 11) also suggests that amino acids are present within the aragonite. These results indicate that organic substances probably played an important role in regulating the entry of $\mathrm{Mg}^{2+}$ into the aragonite crystals. Furthermore, previous studies have shown that corals containing symbiotic zooxanthella have a relatively high content of acidic amino acids, e.g., Glu, which may be the reason for the high $\mathrm{Mg}^{2+}$ content there [53]. Thus, it can be inferred that acidic amino acids, e.g., Glu, may also play the same significant role in the formation of $\mathrm{Mg}^{2+}$-rich aragonite in this study.

Rollion-Bard and Blamart studied the possible controlling factors affecting the entry of $\mathrm{Mg}$ into aragonite and found that the growth rate was the main factor through crystal surface entrapment at crystal defects [55]. It seems impossible that the substitution of Ca by $\mathrm{Mg}$ can occur in the aragonite lattice [17]; however, the Mg cation is thought to be trapped within crystal lattice defects [56,57]. Thus, we propose a new biomineralization model for the incorporation of $\mathrm{Mg}$ into aragonite crystals. Differences in crystal structure between biotic and abiotic aragonite were investigated, and structural analyses showed that the rhombic unit cell of biogenic aragonite in the mollusk was distorted as compared with that of abiotic aragonite [58]. This distinction may be due to the organic substances present in the aragonite crystals [58]. Thus, it can be inferred that one or several kinds of organic material may play a significant role in the incorporation of $\mathrm{Mg}$ into the biotic aragonite crystal lattice in two ways:

(1) On the one hand, organic substances, such as Glu, within the aragonite crystals may cause lattice defects and distortion, which may then become trapping sites for $\mathrm{Mg}$ ions. The crystal lattice distortion of aragonite caused by Glu was simulated using Material Studio software 8.0 (Figure 12). Glu was adsorbed onto the aragonite surfaces through the hydrogen bond between $\mathrm{H}$ of $-\mathrm{COOH}$ in the Glu and $\mathrm{O}$ of $\mathrm{CO}_{3}^{2-}$ on the aragonite surface, and this resulted in energy change and structure optimization. As a result, lattice defects and distortions may appear, and these may provide the trapping sites for $\mathrm{Mg}$ ions.

(2) On the other hand, the adsorption of Glu onto aragonite surfaces is much stronger than that of water molecules, and then Glu may replace some water molecules adsorbed on the crystal surface (Figure 12d). Dehydration of $\left[\mathrm{Mg}\left(\mathrm{H}_{2} \mathrm{O}\right)_{6}\right]^{2+}$ is regarded as the most difficult step to obtain free $\mathrm{Mg}$ ions because much more energy is needed for the dehydration of $\mathrm{Mg}\left[\mathrm{H}_{2} \mathrm{O}\right]_{6}^{2+}$ than that of $\mathrm{Ca}\left[\mathrm{H}_{2} \mathrm{O}\right]_{6}^{2+}[13]$. Thus, due to the presence of hydrated membranes of $\mathrm{Mg}$ ions, the entrance of free magnesium ions into the aragonite lattice becomes difficult. However, abundant Glu on the crystal surface may decrease the energy barrier when $\left[\mathrm{Mg}\left(\mathrm{H}_{2} \mathrm{O}\right)_{6}\right]^{2+}$ ions are dehydrated, resulting in easier dehydration than before [13]. In a word, bacteria and their released substances, including acidic amino acids, may be one of the factors controlling the entry of $\mathrm{Mg}$ into the aragonite lattice. These results help to deepen our understanding of the mineralogical characteristics of magnesium-bearing biogenic aragonite and the precise role that microorganisms and their metabolites play in the process of biomineralization.

\section{Conclusions}

S. warneri $\mathrm{YXY2}$, one moderate halophile, was used to induce the bio-precipitation of carbonate minerals at various $\mathrm{Mg} / \mathrm{Ca}$ ratios. Ammonia, CA and ALP released by YXY2 bacteria resulted in a $\mathrm{pH}$ increase and higher supersaturation, promoting the precipitation of calcite, vaterite, $\mathrm{Mg}$-rich calcite and aragonite. The crystallinity of aragonite decreased with increasing $\mathrm{Mg} / \mathrm{Ca}$ ratios due to the incorporation of $\mathrm{Mg}^{2+}$ ions into the aragonite lattice. The characteristics, such as the preferred orientation, diverse morphologies, abundant organic substances, more negative stable carbon isotope values, the presence of $\mathrm{Mg}^{2+}$ in the biotic aragonite, the higher thermal stability of biotic aragonite, and so on, prove that the minerals obtained in this study were biogenic. EPS acted as the nucleation site. $\mathrm{Ca}^{2+}$ and $\mathrm{Mg}^{2+}$ ions could enter into cells and participate in intracellular biomineralization. The molecular simulation revealed that Glu promoted the entry of $\mathrm{Mg}^{2+}$ ions into the aragonite crystals because Glu could decrease the energy barrier for the dehydration of $\left[\mathrm{Mg}\left(\mathrm{H}_{2} \mathrm{O}\right)_{6}\right]^{2+}$ ions. This study 
may help to further understand the biomineralization mechanisms of carbonate minerals induced by YXY2 bacteria and may provide some insights for the interpretation of the unique characteristics of biotic minerals.

Supplementary Materials: The following are available online at http://www.mdpi.com/2073-4352/10/2/58/s1, Table S1. Mineral phases and crystal parameters of minerals in the experimental groups. Table S2. Crystal parameters of the abiotic and biotic aragonite $(\mathrm{Mg} / \mathrm{Ca}=8)$. Table S3. Parameters of molecular dynamic simulation for the adsorption of Glu onto aragonite surfaces. Figure S1. The phylogenetic tree of YXY2. Figure S2. Ammonia test of $S$. warneri YXY2 bacteria (a1: before adding the Nessler's reagent; a2: after adding the Nessler's reagent; 1: the control group; 2: the experimental group). Figure S3. Rietveld refinement analyses of the biotic minerals cultivated for 14 days $(\mathrm{a}, \mathrm{b}, \mathrm{c}, \mathrm{d}$, and e represent minerals at $\mathrm{Mg} / \mathrm{Ca}$ molar ratios of $0,2,4,6$, and 8, respectively). Figure S4. Mg content within the biotic and abiotic aragonite measured using flame atomic absorption spectrometry.

Author Contributions: Y.H. conceived and designed the experiments; B.S., Y.Z. (Yanhong Zhao) performed the experiments; H.Z., J.Z., Y.Z. (Yifan Zhao) and H.Y. analyzed the results of all the experiments; B.S. and H.Y. wrote the paper; Y.H. and M.E.T. revised the manuscript. All authors have read and agreed to the published version of the manuscript.

Funding: This work was supported by the National Natural Science Foundation of China $(41972108,41772095$, U1663201, 41702131); the Laboratory for Marine Mineral Resources, Qingdao National Laboratory for Marine Science and Technology (MMRZZ201804); Taishan Scholar Talent Team Support Plan for Advanced \& Unique Discipline Areas, Major Scientific and Technological Innovation Projects of Shandong Province (2017CXGC1602, 2017CXGC1603); SDUST Research Fund (2015TDJH101); Natural Science Foundation of Shandong Province (ZR2019MD027, ZR2017BD001); the Scientific and Technological Innovation Project Financially Supported by Qingdao National Laboratory for Marine Science and Technology (2016ASKJ13); Open Fund of the Key Laboratory of Marine Geology and Environment, Chinese Academy of Sciences (MGE2016KG10); Major Innovation Projects of Key R\&D Program of Shandong Province (No.2019JZZY020808); Program for Graduate Science and Technology Innovation of Shandong University of Science and Technology under grant (201810424074, No.2333).

Conflicts of Interest: The authors declare no conflict of interest.

\section{References}

1. Guo, W.; Ma, H.; Li, F.; Jin, Z.D.; Li, J.; Ma, F.; Wang, C. Citrobacter sp. strain GW-M mediates the coexistence of carbonate minerals with various morphologies. Geomicrobiol. J. 2013, 30, 749-757. [CrossRef]

2. Epple, M. Buchbesprechung: Biomineralization principles and concepts in bioinorganic materials chemistry. Von Stephen Mann. Angew. Chem. 2003, 115, 395. [CrossRef]

3. Fu, G.; Valiyaveettil, S.; Wopenka, B.; Morse, D. $\mathrm{CaCO}_{3}$ biomineralization: Acidic 8-kDa proteins isolated from aragonitic abalone shell nacre can specifically modify calcite crystal morphology. Biomacromolecules 2005, 6, 1289-1298. [CrossRef]

4. Holcomb, M.; Cohen, A.; Gabitov, R.; Hutter, J. Compositional and morphological features of aragonite precipitated experimentally from seawater and biogenically by corals. Geochim. Cosmochim. Acta 2009, 73, 4166-4179. [CrossRef]

5. Han, Z.; Li, D.; Zhao, H.; Yan, H.; Li, P. Precipitation of carbonate minerals induced by the halophilic Chromohalobacter Israelensis under high salt concentrations: Implications for natural environments. Minerals 2017, 7, 95. [CrossRef]

6. Qiu, X.; Yao, Y.; Wang, H.; Shen, A.; Zhang, J. Halophilic archaea mediate the formation of proto-dolomite in solutions with various sulfate concentrations and salinities. Front. Microbiol. 2019, 10, 480. [CrossRef] [PubMed]

7. Lian, B.; Hu, Q.; Chen, J.; Ji, J.; Teng, H.H. Carbonate biomineralization induced by soil bacterium Bacillus megaterium. Geochim. Cosmochim. Ac. 2006, 70, 5522-5535. [CrossRef]

8. Han, Z.; Sun, B.; Zhao, H.; Yan, H.; Han, M.; Zhao, Y.; Meng, R.; Zhuang, D.; Li, D.; Ma, Y.; et al. Isolation of Leclercia adcarboxglata strain JLS1 from dolostone sample and characterization of its induced struvite minerals. Geomicrobiol. J. 2017, 34, 500-510. [CrossRef]

9. Han, Z.; Yu, W.; Zhao, H.; Zhao, Y.; Tucker, M.; Yan, H. The significant roles of Mg/Ca ratio, Cl- and $\mathrm{SO}_{4}{ }^{2-}$ in carbonate mineral precipitation by the halophile Staphylococcus epidermis Y2. Minerals 2018, 8, 594. [CrossRef]

10. Cao, C.; Jiang, J.; Sun, H.; Huang, Y.; Tao, F.; Lian, B. Carbonate mineral formation under the influence of limestone-colonizing actinobacteria: Morphology and polymorphism. Front. Microbiol. 2016, 7, 366. [CrossRef] 
11. Rivadeneyra, M.; Martín-Algarra, A.; Sánchez-Navas, A.; Martín-Ramos, D. Carbonate and phosphate precipitation by Chromohalobacter marismortui. Geomicrobiol. J. 2006, 23, 1-13. [CrossRef]

12. Sánchez-Román, M.; Romanek, C.; Fernández-Remolar, D.; Sánchez-Navas, A.; McKenzie, J.; Amils, R.; Vasconcelos, C. Aerobic biomineralization of Mg-rich carbonates: Implications for natural environments. Chem. Geol. 2011, 281, 143-150. [CrossRef]

13. Qiu, X.; Wang, H.; Yao, Y.; Duan, Y. High salinity facilitates dolomite precipitation mediated by Haloferax volcanii DS52. Earth. Planet. Sc. Lett. 2017, 472, 197-205. [CrossRef]

14. Deng, S.; Dong, H.; Lv, G.; Jiang, H.; Yu, B.; Bishop, M. Microbial dolomite precipitation using sulfate reducing and halophilic bacteria: Results from Qinghai Lake, Tibetan Plateau, NW China. Chem. Geol. 2010, 278, 151-159. [CrossRef]

15. Lin, C.Y.; Turchyn, A.; Steiner, Z.; Bots, P.; Lampronti, G.; Tosca, N. The role of microbial sulfate reduction in calcium carbonate polymorph selection. Geochim. Cosmochim. Ac. 2018, 237, 184-204. [CrossRef]

16. Zhuang, D.; Yan, H.; Tucker, M.E.; Zhao, H.; Han, Z.; Zhao, Y.; Sun, B.; Li, D.; Pan, J.; Zhao, Y.; et al. Calcite precipitation induced by Bacillus cereus MRR2 cultured at different $\mathrm{Ca}^{2+}$ concentrations: Further insights into biotic and abiotic calcite. Chem. Geol. 2018, 500, 64-87. [CrossRef]

17. Perri, E.; Tucker, M.; Slowakiewicz, M.; Whitaker, F.; Bowen, L.; Perrotta, I. Carbonate and silicate biomineralization in a hypersaline microbial mat (Mesaieed sabkha, Qatar): Roles of bacteria, extracellular polymeric substances and viruses. Sedimentology 2017, 65, 1213-1245. [CrossRef]

18. Wang, H.; Zeng, C.; Liu, Q.; Liu, D.; Xuan, Q.; Gong, L. Calcium carbonate precipitation induced by a bacterium strain isolated from an oligotrophic cave in Central China. Front. Earth. Sci. China 2010, 4, 148-151. [CrossRef]

19. Kakimoto, S.; Okazaki, K.; Sakane, T.; Imai, K.; Sumino, Y.; Akiyama, S.-I.; Nakao, Y. Isolation and taxonomic characterization of urease-producing bacteria. Agric. Biol. Chem. 1989, 53, 1111-1117. [CrossRef]

20. Vasconcelos, C.; McKenzie, J.A.; Bernasconi, S.; Grujic, D.; Tien, A.J. Microbial mediation as a possible mechanism for natural dolomite formation at low-temperatures. Nature 1995, 377, 220-222. [CrossRef]

21. Achal, V.; Pan, X. Characterization of urease and carbonic anhydrase producing bacteria and their role in calcite precipitation. Curr. Microbiol. 2010, 62, 894-902. [CrossRef] [PubMed]

22. Krause, S.; Liebetrau, V.; Löscher, C.; Böhm, F.; Gorb, S.; Eisenhauer, A.; Treude, T. Marine ammonification and carbonic anhydrase activity induce rapid calcium carbonate precipitation. Geochim. Cosmochim. Ac. 2018, 243, 116-132. [CrossRef]

23. Zhang, X.Y.; Ge, S.-S.; Shao, Q.; Liu, M.; Liu, Q.Y. Synthesis and photocatalytic activity of $\mathrm{CeO}_{2}$ hollow microspheres via yeast template route. Chinese J. Inorg. Chem. 2016, 32, 1535-1542. [CrossRef]

24. Liu, Y.; Xiao, T.; Zengping, N.; Li, H.; Tang, J.; Zhou, G. High cadmium concentration in soil in the three Gorges region: Geogenic source and potential bioavailability. Appl. Geochem. 2013, 37, 149-156. [CrossRef]

25. Zhao, Y.; Yan, H.; Zhou, J.; Tucker, M.E.; Han, M.; Zhao, H.; Mao, G.; Zhao, Y.; Han, Z. Bio-precipitation of calcium and magnesium ions through extracellular and intracellular process induced by Bacillus Licheniformis SRB2. Minerals 2019, 9, 526. [CrossRef]

26. Pan, J.; Zhao, H.; Tucker, M.E.; Zhou, J.; Jiang, M.; Wang, Y.; Zhao, Y.; Sun, B.; Han, Z.; Yan, H. Biomineralization of monohydrocalcite induced by the halophile Halomonas smyrnensis WMS-3. Minerals 2019, 9, 632. [CrossRef]

27. Han, Z.; Gao, X.; Zhao, H.; Tucker, M.; Zhao, Y.; Bi, Z.; Pan, J.; Wu, G.; Yan, H. Extracellular and intracellular biomineralization induced by Bacillus licheniformis DB1-9 at different Mg/Ca molar ratios. Minerals 2018, 8, 585. [CrossRef]

28. Pocker, Y.; Stone, J. The catalytic versatility of erythrocyte carbonic anhydrase. III. Kinetic studies of the enzyme-catalyzed hydrolysis of p-nitrophenyl acetate. Biochemistry 1967, 6, 668-678. [CrossRef]

29. Han, Z.; Wang, J.; Zhao, H.; Tucker, M.E.; Zhao, Y.; Wu, G.; Zhou, J.; Yin, J.; Zhang, H.; Zhang, X.; et al. Mechanism of biomineralization induced by Bacillus subtilis $\mathrm{J} 2$ and characteristics of the biominerals. Minerals 2019, 9, 218. [CrossRef]

30. Khan, M.S.; Garnier, G. Direct measurement of alkaline phosphatase kinetics on bioactive paper. Chem. Eng. Sci. 2013, 87, 91-99. [CrossRef]

31. Murphy, J.; Riley, J. A single-solution method for the determination of soluble phosphate in sea water. J. Mar. Biol. Assoc. Uk. 1958, 37, 9-14. [CrossRef]

32. Zhou, G.-T.; Yao, Q.Z.; Ni, J.; Jin, G. Formation of aragonite mesocrystals and implication for biomineralization. Amer. Mineral. 2009, 94, 293-302. [CrossRef] 
33. Liu, Q.; Yang, Y.; Li, H.; Zhu, R.; Shao, Q.; Yang, S.; Xu, J. NiO nanoparticles modified with5,10,15,20-tetrakis(4-carboxyl pheyl)-porphyrin: Promising peroxidase mimetics for $\mathrm{H}_{2} \mathrm{O}_{2}$ and glucose detection. Biosens. Bioelectron. 2015, 64, 147-153. [CrossRef] [PubMed]

34. Wu, S.; Chiang, C.-Y.; Zhou, W. Formation Mechanism of $\mathrm{CaCO}_{3}$ Spherulites in the Myostracum Layer of Limpet Shells. Crystals 2017, 7, 319. [CrossRef]

35. Braissant, O.; Cailleau, G.; Dupraz, C.; Verrecchia, A. Bacterially induced mineralization of calcium carbonate in terrestrial environments: The role of exopolysaccharides and amino acids. J. Sediment. Res. 2003, 73, 485-490. [CrossRef]

36. Gómez, M.; Bratos Perez, M.A.; Martin-Gil, F.J.; Díez, A.; Rodríguez, J.; Rodríguez, P.; Domingo, A.; Torres, A. Identification of species of Brucella using Fourier Transform Infrared Spectroscopy. J. Microbiol. Meth. 2003, 55, 121-131. [CrossRef]

37. Ni, M.; Ratner, B. Differentiation of calcium carbonate polymorphs by surface analysis techniques - an XPS and TOF-SIMS study. Surf. Interface. Anal. 2008, 40, 1356-1361. [CrossRef]

38. Li, H.; Yao, Q.-Z.; Wang, F.-P.; Huang, Y.-R.; Fu, S.-Q.; Zhou, G.-T. Insights into the formation mechanism of vaterite mediated by a deep-sea bacterium Shewanella piezotolerans WP3. Geochim. Cosmochim. Ac. 2019, 256, 35-48. [CrossRef]

39. Tadier, S.; Rokidi, S.; Rey, C.; Combes, C.; Koutsoukos, P. Crystal growth of aragonite in the presence of phosphate. J. Cryst. Growth. 2017, 458, 44-52. [CrossRef]

40. Li, H.; Yao, Q.-Z.; Wang, Y.-Y.; Li, Y.-L.; Zhou, G.-T. Biomimetic synthesis of struvite with biogenic morphology and implication for pathological biomineralization. Sci. Rep. 2015, 5, 7718. [CrossRef]

41. Sanchez-Roman, M.; Rivadeneyra, M.A.; Vasconcelos, C.; McKenzie, J.A. Biomineralization of carbonate and phosphate by moderately halophilic bacteria. FEMS Microbiol. Ecol. 2007, 61, 273-284. [CrossRef] [PubMed]

42. Wei, S.; Cui, H.; Zhenglong, J.; Liu, H.; He, H.; Fang, N. Biomineralization processes of calcite induced by bacteria isolated from marine sediments. Braz. J. Microbiol. 2015, 46, 455-464. [CrossRef] [PubMed]

43. Xiao, L.; Lian, B. Heterologously expressed carbonic anhydrase from Bacillus mucilaginosus promoting $\mathrm{CaCO}_{3}$ formation by capturing atmospheric $\mathrm{CO}_{2}$. Carbonate. Evaporite. 2016, 31, 39-45. [CrossRef]

44. Innocenti, A.; Mühlschlegel, F.; Hall, R.; Steegborn, C.; Scozzafava, A.; Supuran, C. Carbonic anhydrase inhibitors: Inhibition of the ??-class enzymes from the fungal pathogens Candida albicans and Cryptococcus neoformans with simple anions. Bioorg. Med. Chem. Lett. 2008, 18, 5066-5070. [CrossRef] [PubMed]

45. Mann, S.; Archibald, D.; Didymus, J.; Douglas, T.; Heywood, B.; Meldrum, F.; Reeves, N. Crystallization at inorganic-organic interfaces: Biominerals and biomimetic synthesis. Science 1993, 261, 1286-1292. [CrossRef] [PubMed]

46. Bains, A.; Dhami, N.K.; Mukherjee, A.; Reddy, M.S. Influence of exopolymeric materials on bacterially induced mineralization of carbonates. Appl. Biochem. Biotech. 2015, 175, 3531-3541. [CrossRef]

47. Silyn-Roberts, H.; Sharp, R. Preferred orientation of calcite and aragonite in the reptilian eggshells. P. Roy. Soc. B-Biol. Sci. 1985, 225, 445-455. [CrossRef]

48. Hou, W.T.; Feng, Q. Crystal orientation preference and formation mechanism of nacreous layer in mussel. J. Cryst. Growth. 2003, 258, 402-408. [CrossRef]

49. Davis, K.; Dove, P.; Yoreo, J. Understanding the molecular-scale processes of biomineralization: The role of $\mathrm{Mg}^{2+}$ and $\mathrm{Sr}^{2+}$ in calcite growth. In AGU Fall Meeting Abstracts; Wiley: Hoboken, NY, USA, 2001.

50. Robach, J.S.; Stock, S.R.; Veis, A. Mapping of magnesium and of different protein fragments in sea urchin teeth via secondary ion mass spectroscopy. J. Struct. Biol. 2006, 155, 87-95. [CrossRef]

51. Ma, Y.; Aichmayer, B.; Paris, O.; Fratzl, P.; Meibom, A.; Metzler, R.A.; Politi, Y.; Addadi, L.; Gilbert, P.U.P.A.; Weiner, $\mathrm{S}$. The grinding tip of the sea urchin tooth exhibits exquisite control over calcite crystal orientation and Mg distribution. Proc. Natl. Acad. Sci. USA 2009, 106, 6048-6053. [CrossRef]

52. Finch, A.; Allison, N. Mg structural state in coral aragonite and implications for the paleoenvironmental proxy. Geophys. Res. Lett. 2008, 35. [CrossRef]

53. Meibom, A.; Cuif, J.-P.; Hillion, F.O.; Constantz, B.; Anne, J.-L.; Dauphin, Y.; Watanabe, T.; Dunbar, R.B. Distribution of magnesium in coral skeleton. Geophys. Res. Lett. 2004, 31, L23306. [CrossRef]

54. Gaetani, G.A.; Cohen, A.L.; Wang, Z.; Crusius, J. Rayleigh-based, multi-element coral thermometry: A biomineralization approach to developing climate proxies. Geochim. Cosmochim. Ac. 2011, 75, 1920-1932. [CrossRef] 
55. Rollion-Bard, C.; Blamart, D. Possible controls on Li, Na, and Mg incorporation into aragonite coral skeletons. Chem. Geol. 2015, 396, 98-111. [CrossRef]

56. Mitsuguchi, T.; Uchida, T.; Matsumoto, E.; Isdale, P.; Kawana, T. Variations in Mg/Ca, Na/Ca, and Sr/Ca ratios of coral skeletons with chemical treatments: Implications for carbonate geochemistry. Geochim. Cosmochim. Ac. 2001, 65, 2865-2874. [CrossRef]

57. Marchitto, T.M.; Bryan, S.P.; Doss, W.; McCulloch, M.T.; Montagna, P. A simple biomineralization model to explain $\mathrm{Li}, \mathrm{Mg}$, and Sr incorporation into aragonitic foraminifera and corals. Earth. Planet. Sc. Lett. 2018, 481, 20-29. [CrossRef]

58. Pokroy, B.; Fitch, A.N.; Lee, P.L.; Quintana, J.P.; Caspi, E.a.N.; Zolotoyabko, E. Anisotropic lattice distortions in the mollusk-made aragonite: A widespread phenomenon. J. Struct. Biol. 2006, 153, 145-150. [CrossRef]

(C) 2020 by the authors. Licensee MDPI, Basel, Switzerland. This article is an open access article distributed under the terms and conditions of the Creative Commons Attribution (CC BY) license (http://creativecommons.org/licenses/by/4.0/). 